\title{
Simulated Experiment Study of Factors Influencing the Hydration Activity of f-CaO in Basic Oxygen Furnace Slag
}

\author{
Ruiquan Jia and Jiaxiang Liu \\ Beijing Key Laboratory of Electrochemical Process and Technology for Materials, Beijing University of Chemical Technology, \\ Beijing 100029, China
}

Correspondence should be addressed to Jiaxiang Liu; ljxpost@263.net

Received 26 June 2016; Revised 17 September 2016; Accepted 17 October 2016

Academic Editor: Paulo H. R. Borges

Copyright (C) 2016 R. Jia and J. Liu. This is an open access article distributed under the Creative Commons Attribution License, which permits unrestricted use, distribution, and reproduction in any medium, provided the original work is properly cited.

The compositions and formation process of $\mathrm{f}-\mathrm{CaO}$ in $\mathrm{BOF}$ slag were revealed and simulated to understand its expansion rules and why its hydration activity is low. $\mathrm{BSE}$ showed the compositions of $\mathrm{f}-\mathrm{CaO}$, which included calcium iron phase and calcium iron manganese phase, were diverse. The hydration activity sequence was $\mathrm{Ca}_{2} \mathrm{Fe}_{2} \mathrm{O}_{5}$ and $\mathrm{Ca}_{3} \mathrm{Fe}_{1.5} \mathrm{Mn}_{1.5} \mathrm{O}_{8}$ in tricomponent $\mathrm{f}-\mathrm{CaO}$ $<\mathrm{CaO}$ in tricomponent $\mathrm{f}-\mathrm{CaO}<$ monocomponent $\mathrm{f}-\mathrm{CaO}$; only $\mathrm{Ca}_{2} \mathrm{Fe}_{2} \mathrm{O}_{5}$ and $\mathrm{Ca}_{3} \mathrm{Fe}_{1.5} \mathrm{Mn}_{1.5} \mathrm{O}_{8}$ were hard to hydrate, and the volume expansion rates of the tricomponent $\mathrm{f}-\mathrm{CaO}$ varied with different compositions. Inductively, in $\mathrm{BOF}$ slag, the hydration activity sequence was solid solutions $\mathrm{CaO}-\mathrm{FeO}$ and $\mathrm{CaO}-\mathrm{FeO}_{x}-\mathrm{MnO}_{y}$ in tricomponent $\mathrm{f}-\mathrm{CaO}<\mathrm{CaO}$ in tricomponent $\mathrm{f}-\mathrm{CaO}<$ monocomponent $\mathrm{f}-\mathrm{CaO}$; the volume expansion rates of tricomponent $\mathrm{f}-\mathrm{CaO}$ changed with different compositions, and $\mathrm{CaO}_{-} \mathrm{FeO}{ }_{x}$ and $\mathrm{CaO}-\mathrm{FeO}_{x}-\mathrm{MnO}_{y}$ were difficult to hydrate. The reason why solid solutions $\mathrm{CaO}-\mathrm{FeO}$ and $\mathrm{CaO}-\mathrm{FeO} \mathrm{O}_{x}-\mathrm{MnO}_{y}$ were hard to hydrate was that their hydration reaction driving force, which is the absolute value of standard molar reaction Gibbs functions, decreased.

\section{Introduction}

Basic Oxygen Furnace (BOF) slag is the industrial by-product from the steel-refining process in a conversion furnace, and its output accounts for $15 \sim 20 \%$ by mass of the total output of crude steel [1]. In China, $1.5 \times 10^{8}$ tons of BOF slag was produced in 2015 [2]. However, the current utilization rate of BOF slag in China is only $22 \%$. Massive amounts of BOF slag have been dumped as waste, which not only leads to the occupation of farm land and serious pollution to the environment but is also an extreme waste of resources. This situation also has a very negative effect on steel enterprise regarding sustainable development [3]. In China, approximately two billion tons of Ordinary Portland Cement (OPC) is produced every year $[4,5]$. BOF slag and OPC possess the same chemical and mineral compositions, and it is possible to use BOF slag in cement and concrete industry as a resource; meanwhile, this use is effective to realize a high added value application and sustainable development. However, its low hydration activity $[6,7]$ and the volume expansion that occurs after blended OPC binder containing BOF slag (CBS) hardens [8-10] have restricted the application of BOF slag in cement and concrete industry. It is imperative to find ways to stimulate its hydration activity and resolve the volume expansion of BOF slag.

There have been a great number of studies on stimulating the hydration activity of BOF slag, but there have been very limited studies on resolving the volume expansion of $\mathrm{BOF}$ slag. Currently, it is universally acknowledged that there is the possibility that $\mathrm{f}-\mathrm{CaO}$ and $\mathrm{f}-\mathrm{MgO}$, which are in a dead-burnt state and whose hydration activity is very low, will continue to slowly hydrate in BOF slag after CBS hardens, causing a volume expansion, which may damage the construction. In this study, $\mathrm{f}-\mathrm{CaO}$ was considered to be the major factor of the volume expansion of $\mathrm{BOF}$ slag. $\mathrm{F}-\mathrm{CaO}$, which will cause the volume expansion after CBS hardens, is a mineral phase in $\mathrm{BOF}$ slag, and its main composition is $\mathrm{CaO}$ [11-13]. To address the volume expansion caused by $\mathrm{f}-\mathrm{CaO}$, Wang et al. [8] have found a theoretical equation based on both chemical reaction and physical changes of $\mathrm{f}-\mathrm{CaO}$ in $\mathrm{BOF}$ slag during the hydration process to predict the volume expansion of BOF slag. The calculated volume expansion data can be 
used as evaluation criteria for a given slag that is used in an engineering application, which is significant to applying BOF slag in OPC. At the same time, Wang [9] has noted that the volume expansion data of BOF slag tested by the current ASTM (2006) standard test method [10] are not directly related to the expansion behavior of BOF slag under confined conditions. The expansion force is the direct factor, and the allowable stress of a rigid matrix should also be considered when BOF slag is applied in OPC. Kuo et al. $[14,15]$ have put forward that high temperature rapid catalytic technology can accelerate $\mathrm{f}-\mathrm{CaO}$ hydration and forecast the volume expansion within a short time. Moreover, it can verify the volumetric stability of a steel material, identify the possible expansion risk before use, and forecast the durability of concrete mixed with different amounts of BOF slag.

So far, the literature has shown that there has been a great amount of attention paid by exploring the relationship between a certain amount of $\mathrm{f}-\mathrm{CaO}$ and the volume expansion that is caused. However, a limited number of studies have revealed a clear explanation of the causes related to the low hydration activity of $\mathrm{f}-\mathrm{CaO}$. Therefore, the current aims to resolve volume expansion and establish evaluation criteria are difficult and, to a certain extent, rely on experience. Therefore, it is theoretically and practically significant to study how the factors that influence the hydration activity of $\mathrm{f}-\mathrm{CaO}$ lead to a minimal hydration activity of $\mathrm{f}-\mathrm{CaO}$.

Through a molten temperature of approximately $1600^{\circ} \mathrm{C}$, $\mathrm{f}-\mathrm{CaO}$ in BOF slag is in a dead-burnt state, and the compositions and the distribution of $\mathrm{f}-\mathrm{CaO}$ are heterogeneous. It is possible that iron oxide $\left(\mathrm{FeO}_{x}\right)$ and manganese oxide $\left(\mathrm{MnO}_{y}\right)$ may dissolve in $\mathrm{f}-\mathrm{CaO}$ during the steelmaking process [1113]. The steelmaking process occurs at a high temperature (about $1600^{\circ} \mathrm{C}$ ) and oxidation state [16]. Under this condition, transition metals, such as $\mathrm{Fe}$ and $\mathrm{Mn}$, often form nonstoichiometric oxides $[17,18]$. If $\mathrm{f}-\mathrm{CaO}$ is transformed into the combination of metal oxides, it will present with the form of $\mathrm{CaO} \cdot a \mathrm{FeO}_{x} \cdot b \mathrm{MnO}_{y}[12]$. The values of $a, b, x$, and $y$ of $\mathrm{f}-\mathrm{CaO}$ in different areas of BOF slag are different and uncertain.

Taking the formation process and the compositions of $\mathrm{f}-\mathrm{CaO}$ into consideration, the factors that influence the hydration activity of $\mathrm{f}-\mathrm{CaO}$ are absolutely connected with both the time of high temperature process and dissolved $\mathrm{FeO}_{x}$ and $\mathrm{MnO}_{y}$. Under the influence of these factors, the hydration activity of $\mathrm{f}-\mathrm{CaO}$ may become low. Since the system of BOF slag is very complex, the relationship between the hydration activity of $\mathrm{f}-\mathrm{CaO}$ and the duration of the high temperature process, especially the quantitative relationship between the hydration activity of $\mathrm{f}-\mathrm{CaO}$ and its compositions, is still not definite.

With the aim of better understanding the compositions of $\mathrm{f}-\mathrm{CaO}$ in $\mathrm{BOF}$ slag, why the hydration activity of $\mathrm{f}$ $\mathrm{CaO}$ is low, and its expansion rules, as well as providing theoretical support to address the volume expansion caused by $\mathrm{f}-\mathrm{CaO}$, first, the compositions and formation process of $\mathrm{f}$ $\mathrm{CaO}$ in different $\mathrm{BOF}$ slags were revealed using backscattered electron images (BSE) and energy dispersive analysis (EDS) of scanning electron microscope (SEM) images. Secondly, based on these observations, the formation process and compositions of $\mathrm{f}-\mathrm{CaO}$ were simply simulated through the calcination experiment. Simulated monocomponent $\mathrm{f}-\mathrm{CaO}$ is not the same but it is similar to monocomponent $\mathrm{f}-\mathrm{CaO}$ in $\mathrm{BOF}$ slag and tricomponent $\mathrm{f}-\mathrm{CaO}$ of $\mathrm{CaO} \cdot a \mathrm{FeO}_{1.5} \cdot b \mathrm{MnO}_{2}$ system is not the same but it is similar to the tricomponent $\mathrm{f}-\mathrm{CaO}$ of $\mathrm{CaO} \cdot a \mathrm{FeO}_{x} \cdot b \mathrm{MnO}_{y}$ system in $\mathrm{BOF}$ slag. These components were thoroughly studied by scanning electron microscope (SEM), X-ray diffraction (XRD), energy dispersive spectrometer mapping (EDS-mapping), and hydration heat evolution test. The latter was used to explore the influence mechanisms of the calcination time on the hydration activity of monocomponent $\mathrm{f}-\mathrm{CaO}$ and dissolved $\mathrm{Fe}_{2} \mathrm{O}_{3}$ and $\mathrm{MnO}_{2}$ on the hydration activity of tricomponent $\mathrm{f}-\mathrm{CaO}$ of $\mathrm{CaO} \cdot a \mathrm{FeO}_{1.5} \cdot b \mathrm{MnO}_{2}$ system. The aim of this study was to provide useful fundamental knowledge regarding complex systems by studying simplified systems. Then, the influence mechanisms were extended to monocomponent $\mathrm{f}-\mathrm{CaO}$ and tricomponent $\mathrm{f}-\mathrm{CaO}$ of $\mathrm{CaO} \cdot a \mathrm{FeO}_{x} \cdot b \mathrm{MnO}_{y}$ system because of their similarity. Finally, the main mechanisms behind tricomponent $\mathrm{f}-\mathrm{CaO}$ of $\mathrm{CaO} \cdot a \mathrm{FeO}_{x} \cdot b \mathrm{MnO}_{y}$ system were confirmed by thermodynamic theory. Thermodynamic theory was applied to confirm why the hydration activity of solid solutions $\mathrm{CaO}-\mathrm{FeO}_{x}$ and $\mathrm{CaO}-\mathrm{FeO}_{x}-\mathrm{MnO}_{y}$ in tricomponent $\mathrm{f}-\mathrm{CaO}$ in $\mathrm{BOF}$ slag was low and weaker than that of $\mathrm{CaO}$.

\section{Materials and Methods}

2.1. Materials. Four types of BOF slags were obtained from Jiangsu Tieben Steel and Iron Co., Ltd.; Ma'anshan Steel and Iron Co., Ltd.; Cangzhou Steel and Iron Co., Ltd.; and Baoshan Steel and Iron Co., Ltd., being denominated as SS, MS, CS, and BS, respectively. They were treated by heatstewed process and then underwent natural cooling in warehouse. The chemical compositions of the BOF slags were determined by wavelength dispersive X-ray fluorescence (XRF) spectrometry (Thermo Electron ADVANT' XP). The samples were scanned over a range of $5^{\circ}$ and $90^{\circ} 2 \theta$. The scans were measured in step scan mode at $2 \mathrm{~s}$ per $0.02^{\circ}$ $2 \theta$. Their chemical compositions and the average chemical compositions of BOF slag in China are given in Table $1[2,3]$. From Table 1, it can be seen that the four types of BOF slags are representative in China.

The commercial materials used in this study included analytical grade $\mathrm{CaO}$ (Sinopharm Chemical Reagent Co., Ltd.), $\mathrm{Fe}_{2} \mathrm{O}_{3}$ (Xilong Chemical Co., Ltd.), $\mathrm{MnO}_{2}$ (Xilong Chemical Co., Ltd.), and deionized water (self-manufacture).

2.2. Sample Preparation. BOF slag particles were crushed, rubbed, and inserted in a mould to be polished achieving a smoothness $\leq 0.5 \mathrm{um}$. Subsequently, the samples were washed and coated by carbon film.

Analytical grade $\mathrm{CaO}$ was placed in a $\varphi 50 \mathrm{~mm} \times 10 \mathrm{~mm}$ cylindrical mould under a pressure of $20 \mathrm{MPa}$ for $3 \mathrm{~min}$ and then demoulded; calcinated for $1,3,5$, and $7 \mathrm{~h}$ at $1600^{\circ} \mathrm{C}$ in the electric furnace (Luoyang Shenjia Kiln Co., Ltd., SSJ17 ); and cooled in air rapidly to prepare the four monocomponent f-CaO samples. After the calcinations, the samples were fractured, milled, and sieved below $180 \mathrm{um}$. Finally, the samples were stored in a dryer for the tests. 
TABLE 1: Chemical composition of BOF slag from different steel plants and the average composition in China.

\begin{tabular}{|c|c|c|c|c|c|c|c|c|c|c|}
\hline \multirow[b]{2}{*}{ Source } & \multicolumn{10}{|c|}{ Chemical composition (w/\%) } \\
\hline & $\mathrm{CaO}$ & $\mathrm{SiO}_{2}$ & $\mathrm{Al}_{2} \mathrm{O}_{3}$ & $\begin{array}{r}\mathrm{Fe}_{2} \mathrm{O}_{3} \\
(\mathrm{FeO})\end{array}$ & $\mathrm{MgO}$ & $\mathrm{MnO}$ & $\mathrm{P}_{2} \mathrm{O}_{5}$ & $\mathrm{TiO}_{2}$ & Others & $\mathrm{f}-\mathrm{CaO}$ \\
\hline SS & 43.29 & 13.63 & 3.23 & 24.34 & 10.37 & 1.05 & 2.78 & 0.56 & 0.75 & 5.68 \\
\hline MS & 41.4 & 9.79 & 2.69 & 25.25 & 13.6 & 4.67 & 0.98 & 0.79 & 0.83 & 6.29 \\
\hline CS & 37.37 & 12.21 & 1.01 & 27.90 & 11.5 & 3.32 & 4.10 & 1.02 & 1.37 & 4.19 \\
\hline BS & 39.42 & 11.63 & 0.83 & 30.43 & 8.50 & 2.21 & 3.23 & 0.67 & 3.08 & 4.81 \\
\hline BOF slag & $40 \sim 50$ & $10 \sim 15$ & $1 \sim 5$ & $24 \sim 28$ & $10 \sim 12$ & $<5$ & $<8$ & $<2$ & l & $<10$ \\
\hline
\end{tabular}

The three samples of tricomponent $\mathrm{f}-\mathrm{CaO}$ of $\mathrm{CaO} \cdot a \mathrm{FeO}_{1.5} \cdot b \mathrm{MnO}_{2}$ system were prepared from mixing analytical grade $\mathrm{CaO}, \mathrm{Fe}_{2} \mathrm{O}_{3}$, and $\mathrm{MnO}_{2}$ according to $a$ and $b$ that were equal to 0.17 and $0.03,0.14$ and $0.06,0.1$, and 0.1 , separately, and then, the other procedures were the same as above, except that the calcination time was $3 \mathrm{~h}$. The nomenclature used for the three samples of the tricomponent $\mathrm{f}-\mathrm{CaO}$ of $\mathrm{CaO} \cdot a \mathrm{FeO}_{1.5} \cdot b \mathrm{MnO}_{2}$ system is $\mathrm{C} \cdot 0.17 \mathrm{~F} \cdot 0.03 \mathrm{M}$, $\mathrm{C} \cdot 0.14 \mathrm{~F} \cdot 0.06 \mathrm{M}$, and $\mathrm{C} \cdot 0.1 \mathrm{~F} \cdot 0.1 \mathrm{M}$ according to the difference of $a$ and $b$. C, F, and $\mathrm{M}$ represent $\mathrm{CaO}, \mathrm{FeO}_{1.5}$, and $\mathrm{MnO}_{2}$, respectively. $\mathrm{Ca}_{2} \mathrm{Fe}_{2} \mathrm{O}_{5}$, whose molar ratio of $\mathrm{CaO}$ to $\mathrm{Fe}_{2} \mathrm{O}_{3}$ was 2, and $\mathrm{Ca}_{3} \mathrm{Fe}_{1.5} \mathrm{Mn}_{1.5} \mathrm{O}_{8}$, whose molar ratio of $\mathrm{CaO}$, $\mathrm{Fe}_{2} \mathrm{O}_{3}$, and $\mathrm{MnO}_{2}$ was $4: 1: 2$, was prepared by similar procedures.

\subsection{Methods}

2.3.1. The Compositions of $f-C a O$ in the Four Types of BOF Slags. The backscattered electron image (BSE) was used to observe the micromorphology of the mineral phase in solid matter, in which brighter area corresponds to higher atomic number. The morphology and distribution of the mineral phase in BOF slags were observed using BSE, and, with the energy dispersive spectrometer analysis (EDS), the element compositions of $\mathrm{f}-\mathrm{CaO}$ in $\mathrm{BOF}$ slags were revealed by frequency histogram method in statistics.

\subsubsection{Simulated Monocomponent $f$-CaO Calcinated for Different Times}

(1) XRD Characterization. The monocomponent f-CaO samples were ground to $45 \mathrm{um}$, and then the sieved samples were used for XRD (Siemens D5000) with a scanning range between $5^{\circ}$ and $90^{\circ} 2 \theta$ at a scanning speed of $1 \mathrm{~s} / \mathrm{step}$ and a resolution of $0.05^{\circ} /$ step. The X-ray diffraction patterns were analyzed by the diffraction software Jade- 6 equipped with the ICCD (International Centre for Diffraction Data) PDF-2 database to calculate the crystalline sizes of the monocomponent f-CaO samples using the Scherrer equation [19].

(2) SEM Characterization. The fractured monocomponent f-CaO samples were coated with gold and observed by a SEM (Japanese Electronics Co., Ltd., JSW-780f) to analyse the influence of the calcination time on the microtopography of the monocomponent $\mathrm{f}-\mathrm{CaO}$ samples.
(3) Hydration Heat Evolution Test. The monocomponent f$\mathrm{CaO}$ samples, whose initial masses were $0.6 \mathrm{~g}$, were for the hydration heat evolution test at a water/powder mass ratio $=10 / 3$ at $20^{\circ} \mathrm{C}$ with isothermal calorimetry (Toni Technik $\mathrm{GmBH}$, Germany, ToniDCA7338, sensitivity ratio $0.2 \mathrm{~J} / \mathrm{g}$ ). The results represent the hydration activity of the samples.

\subsubsection{Simulated Tricomponent $f$-CaO of $\mathrm{CaO} \cdot a \mathrm{FeO}_{1.5} \cdot \mathrm{MMnO}_{2}$ System}

(1) XRD Characterization. The samples of tricomponent $\mathrm{f}$ $\mathrm{CaO}$ of $\mathrm{CaO} \cdot a \mathrm{FeO}_{1.5} \cdot b \mathrm{MnO}_{2}$ system were ground below $45 \mathrm{um}$. Then, the sieved samples were dehydrated, hydrated at $20^{\circ} \mathrm{C}$ after $36 \mathrm{~h}$, and autoclaved after $3 \mathrm{~h}(P=2.0 \mathrm{MP}, T=$ $216^{\circ} \mathrm{C}$ ). The samples were used for XRD (Siemens D5000) with a scanning range between $10^{\circ}$ and $50^{\circ} 2 \theta$, a scanning speed of $1 \mathrm{~s} /$ step, and a resolution of $0.02^{\circ} /$ step. $\mathrm{Ca}_{2} \mathrm{Fe}_{2} \mathrm{O}_{5}$ and $\mathrm{Ca}_{3} \mathrm{Fe}_{1.5} \mathrm{Mn}_{1.5} \mathrm{O}_{8}$ and the products of $\mathrm{Ca}_{2} \mathrm{Fe}_{2} \mathrm{O}_{5}$ and $\mathrm{Ca}_{3} \mathrm{Fe}_{1.5} \mathrm{Mn}_{1.5} \mathrm{O}_{8}$ hydrated at $20^{\circ} \mathrm{C}$ after $28 \mathrm{~d}$ were also used for XRD under the similar condition, except that the scanning range was between $20^{\circ}$ and $70^{\circ} 2 \theta$. The X-ray diffraction patterns were analyzed by the diffraction software Jade- 6 in Section 2.3.2(1). The differences in the compositions of the samples were analysed before and after hydration under different conditions.

(2) EDS-Mapping Characterization. The fractured samples were observed by EDS-mapping (Hitachi Co., Ltd., HITACHIS-47000) to identify the distribution patterns and interactions of different phases in tricomponent $\mathrm{f}-\mathrm{CaO}$ of $\mathrm{CaO} \cdot a \mathrm{FeO}_{1.5} \cdot b \mathrm{MnO}_{2}$ system.

(3) Hydration Heat Evolution Test. This test was the same as in Section 2.3.2 (3), except that the samples were tricomponent $\mathrm{f}-\mathrm{CaO}$ of $\mathrm{CaO} \cdot a \mathrm{FeO}_{1.5} \cdot b \mathrm{MnO}_{2}$ system.

\section{Results and Discussion}

\subsection{The Morphology of Mineral Phase and the Element Compositions of $\mathrm{f}$-CaO in BOF Slags}

3.1.1. The Morphology of Mineral Phase in BOF Slags. Figure 1 shows the BSE images of the four types of BOF slags. With EDS for every unique area, it can be found that the black calcium silicate phase marked by A had a round or leaf shape; 

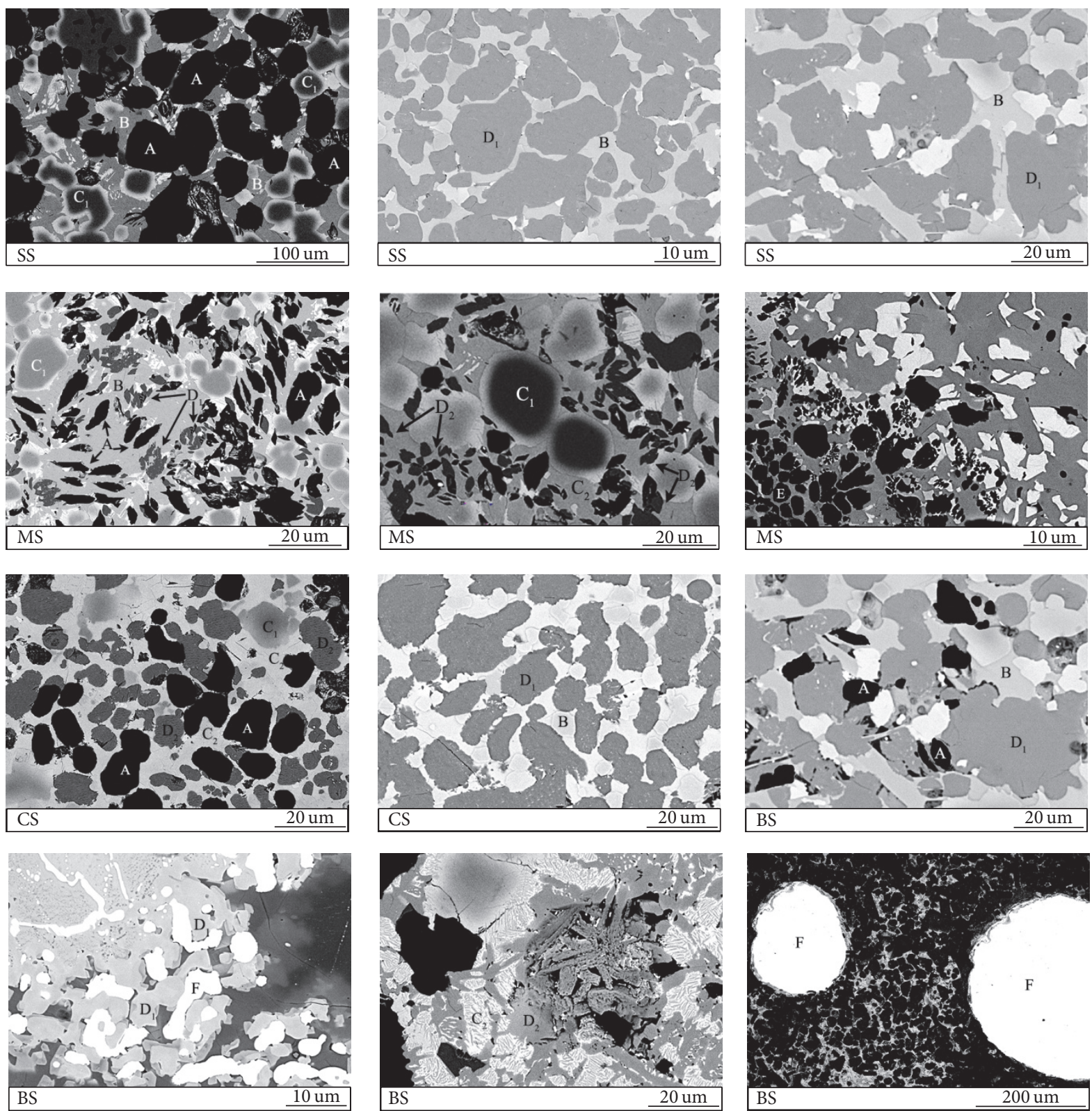

FIgURE 1: BSE images of the four types of BOF slag.

the white calcium iron aluminium phase indicated by B had a crosslinked shape; the iron magnesium phase, which is labelled by $\mathrm{C}_{1}$, was black in the center and white at the edge; the iron magnesium manganese calcium phase labelled by $\mathrm{C}_{2}$ was light grey and in an irregular or striation shape; the calcium iron phase marked by $\mathrm{D}_{1}$ had a large particle shape; and the gathering calcium iron manganese phase shown as $\mathrm{D}_{2}$ had a grey small particle shape. There was a small amount of $\mathrm{f}-\mathrm{MgO}$, labelled by $\mathrm{E}$ that is shown by a black small particle shape as well as Fe particles, indicated as F, that had a light and round shape. As shown in Figure 1, the mineral phase distribution is not uniform. Although they were in the same phase, for example, the black calcium silicate phase, their morphology, and distribution were different in different BOF slags.
F-CaO in BOF slag was considered as a phase which includes not only main $\mathrm{CaO}$ but also some iron oxide $\left(\mathrm{FeO}_{x}\right)$ and manganese oxide $\left(\mathrm{MnO}_{y}\right)$ [11-13]. From the above observations, there was the possibility that calcium iron phase $\left(D_{1}\right)$ and calcium iron manganese phase $\left(D_{2}\right)$ were classified as $\mathrm{f}-\mathrm{CaO}$. In the following section, the element compositions of calcium iron phase and calcium iron manganese phase were analysed by frequency histogram method in statistics to identify whether the calcium iron phase and calcium iron manganese phase could be regarded as $\mathrm{f}-\mathrm{CaO}$ or not.

3.1.2. The Element Compositions of the Calcium Iron Phase and Calcium Iron Manganese Phase in BOF Slags. Frequency histogram method in statistics was used to reveal the element 

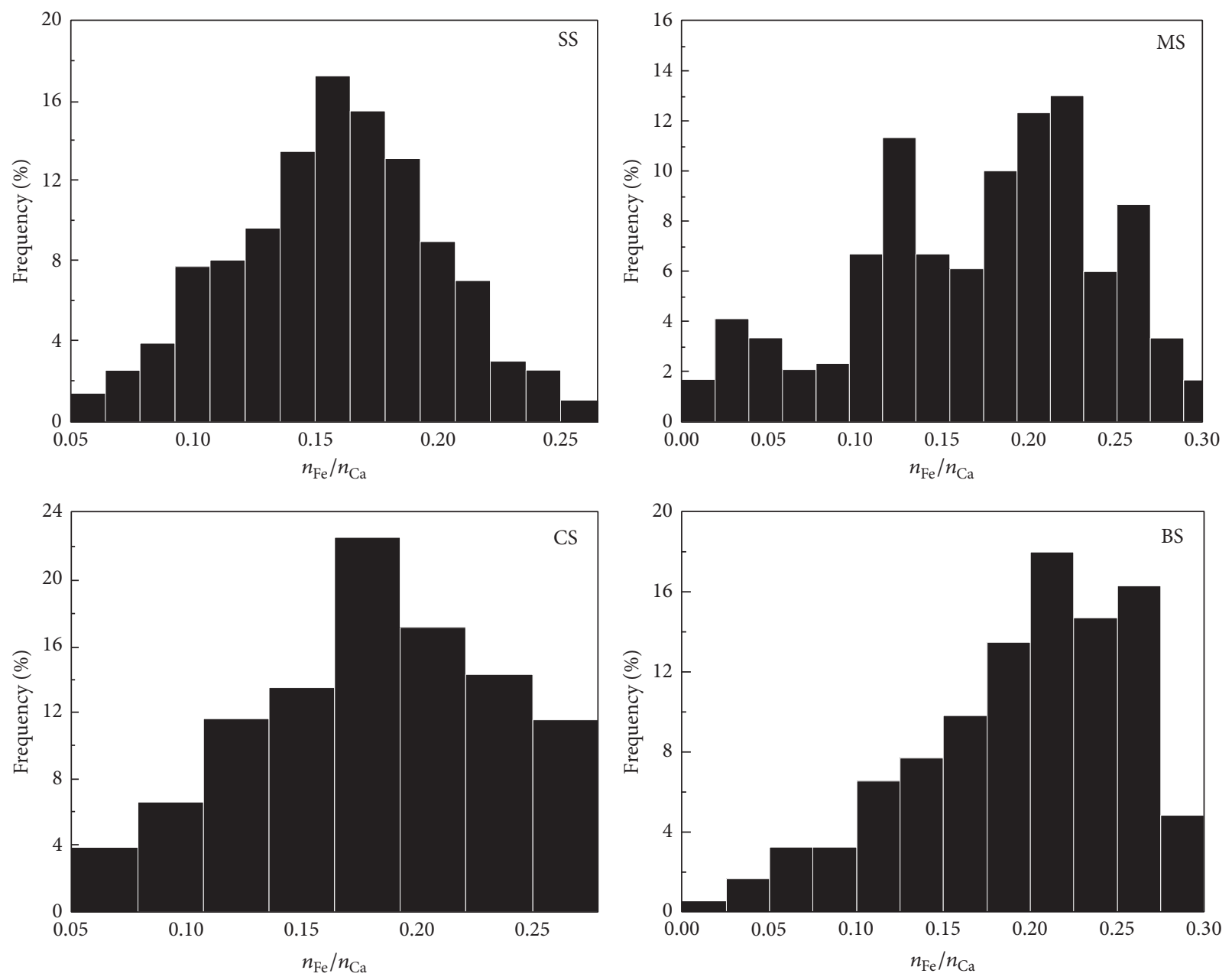

FIGURE 2: Frequency patterns of $n_{\mathrm{Fe}} / n_{\mathrm{Ca}}$ in calcium iron phase of the four types of BOF slag.

compositions of calcium iron phase and calcium iron manganese phase in BOF slags.

(1) The Element Compositions of Calcium Iron Phase. Figure 2 presents frequency histograms of the mole ratio of Fe to $\mathrm{Ca}$ in the calcium iron phase of the four types of BOF slags. In the BSE images, 70 microareas in BS, 90 microareas in MS, 50 microareas in CS, and 70 microareas in BS were analysed by EDS, producing the frequency histograms of the mole ratio of Fe to Ca. Figure 2 indicated that the frequency histograms of $n_{\mathrm{Fe}} / n_{\mathrm{Ca}}$ in the calcium iron phase were irregular and varied in different BOF slags, but their values were all less than 0.3. Therefore, the calcium iron phase in BOF slags was a phase of $\mathrm{CaO} \cdot a \mathrm{FeO}_{x}$ system, whose compositions were not fixed.

(2) The Element Compositions of Calcium Iron Manganese Phase. Figure 3 shows frequency histograms of the mole ratio of $(\mathrm{Fe}+\mathrm{Mn})$ to $\mathrm{Ca}$ in the calcium iron manganese phase of the three types of BOF slags. In BSE images, the calcium iron manganese phase was not found in SS, and 70 microareas in MS, 90 microareas in CS, and 50 microareas in BS were analysed by EDS, producing the frequency histograms of the mole ratio of $(\mathrm{Fe}+\mathrm{Mn})$ to $\mathrm{Ca}$. Based on Figure 2, it can be obtained that Figures 3 and 2 possess similar characteristics. The frequency histograms of $\left(n_{\mathrm{Fe}}+n_{\mathrm{Mn}}\right) / n_{\mathrm{Ca}}$ in the calcium iron manganese phase were irregular and varied in different BOF slags, and the values were all less than 0.5. Therefore, the calcium iron manganese phase in BOF slags was a phase of $\mathrm{CaO} \cdot a \mathrm{FeO}_{x} \cdot b \mathrm{MnO}_{y}$ system, whose compositions were diverse.

It can be concluded that the calcium iron phase and calcium iron manganese phase could be regarded as $\mathrm{f}-\mathrm{CaO}$ because $\mathrm{CaO}$ was the main component and $\mathrm{FeO}_{x}$ and $\mathrm{MnO}_{y}$ were minor components.

Table 2 is frequency table of elements in the calcium iron manganese phase of the three types of BOF slags. It is evident that the average contents of $\mathrm{Ca}, \mathrm{Fe}$, and $\mathrm{Mn}$ decreased gradually, and although Figure 3 gives that the frequency histogram of $\left(n_{\mathrm{Fe}}+n_{\mathrm{Mn}}\right) / n_{\mathrm{Ca}}$ in the calcium iron manganese phase was irregular, the average values of $\left(n_{\mathrm{Fe}}+n_{\mathrm{Mn}}\right) / n_{\mathrm{Ca}}$ were about 0.2 . From Figure 1, it is clear that the $\mathrm{f}-\mathrm{CaO}$ of the calcium iron phase was adjacent to the calcium iron aluminium phase or $\mathrm{Fe}$ and that the $\mathrm{f}-\mathrm{CaO}$ of the calcium iron manganese phase was close to the iron magnesium manganese calcium phase. From this, it can be speculated that the compositional difference between the $\mathrm{f}-\mathrm{CaO}$ of 

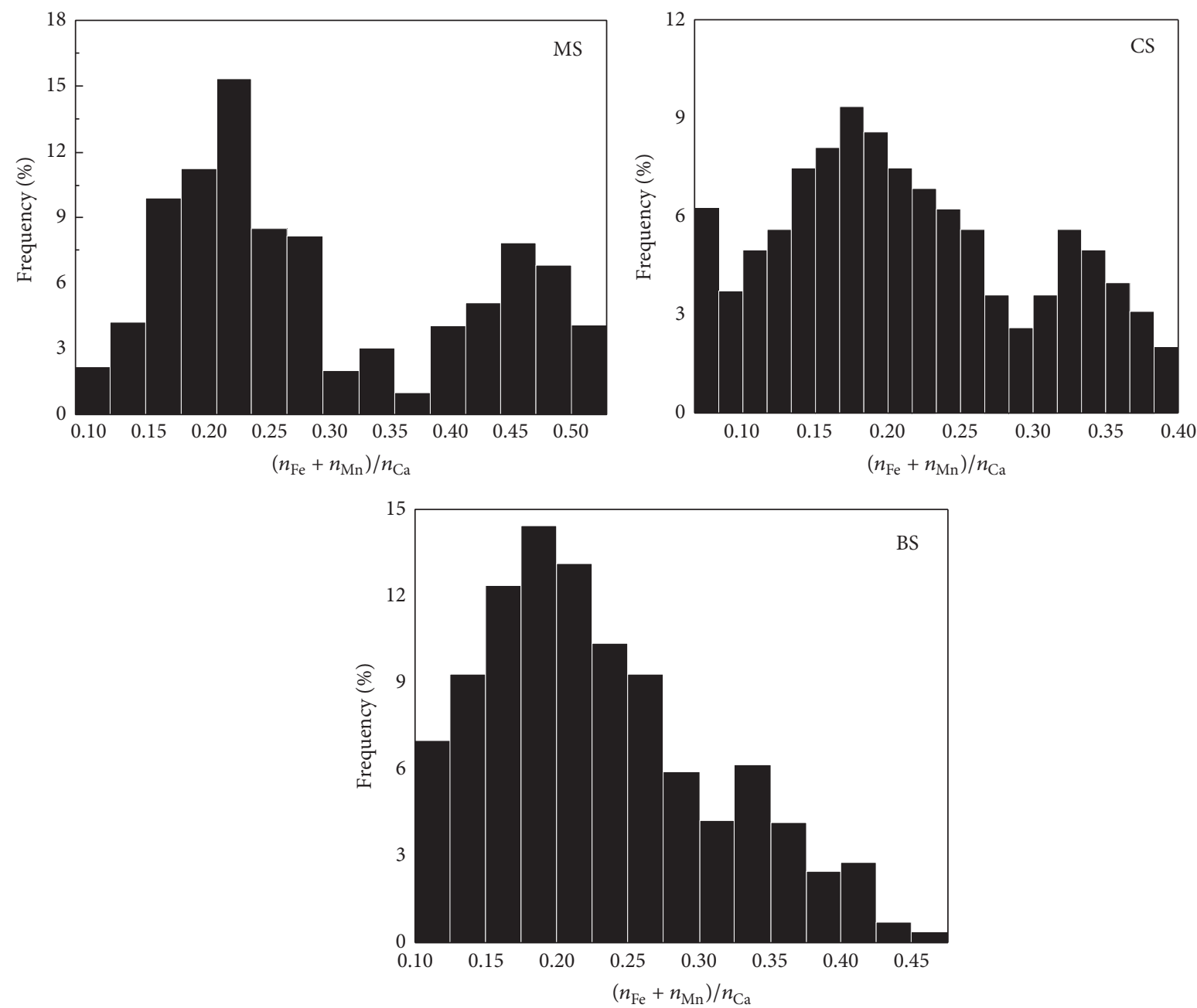

Figure 3: Frequency patterns of $\left(n_{\mathrm{Fe}}+n_{\mathrm{Mn}}\right) / n_{\mathrm{Ca}}$ in calcium iron manganese phase of the three types of BOF slag.

TABLE 2: Frequency table of elements in calcium iron manganese phase of BOF slags from different steel plants.

\begin{tabular}{|c|c|c|c|c|c|c|}
\hline \multirow{2}{*}{ Type } & \multirow{2}{*}{ Microarea number } & \multirow{2}{*}{ Parameter } & \multicolumn{3}{|c|}{ Element number/\% } & \multirow{2}{*}{$\begin{array}{c}\text { Molar ratio } \\
(\mathrm{Fe}+\mathrm{Mn}) / \mathrm{Ca}\end{array}$} \\
\hline & & & $\mathrm{Ca}$ & $\mathrm{Fe}$ & $\mathrm{Mn}$ & \\
\hline \multirow{2}{*}{ MS } & \multirow{2}{*}{100} & Range & $30.13-47.41$ & $2.81-9.70$ & $0.78-6.51$ & $0.09-0.52$ \\
\hline & & Average & 45.28 & 5.85 & 4.20 & 0.22 \\
\hline \multirow{2}{*}{ CS } & \multirow{2}{*}{150} & Range & $32.71-48.27$ & $1.92-7.81$ & $1.29-5.71$ & $0.07-0.40$ \\
\hline & & Average & 41.50 & 4.56 & 3.06 & 0.18 \\
\hline \multirow{2}{*}{ BS } & \multirow{2}{*}{110} & Range & $29.42-45.91$ & $3.71-10.07$ & $0.63-4.62$ & $0.10-0.47$ \\
\hline & & Average & 37.59 & 5.26 & 2.61 & 0.21 \\
\hline
\end{tabular}

the calcium iron phase and the $\mathrm{f}-\mathrm{CaO}$ of the calcium iron manganese phase was due to the difference of the phases adjacent to different $\mathrm{f}-\mathrm{CaO}$. In the high temperature process of steelmaking, some $\mathrm{FeO}_{x}$ dissolved in $\mathrm{CaO}$, which was next to the calcium iron aluminium phase or $\mathrm{Fe}$, forming $\mathrm{f}-\mathrm{CaO}$ of the calcium iron phase, and both $\mathrm{FeO}_{x}$ and $\mathrm{MnO}_{y}$ dissolved in $\mathrm{CaO}$ adjacent to the iron magnesium manganese calcium phase to form the $\mathrm{f}-\mathrm{CaO}$ of the calcium iron manganese phase. In the process of solid solution formation, compared with the radii of $\mathrm{Mg}^{2+}$ in $\mathrm{MgO}$ and $\mathrm{Al}^{3+}$ in $\mathrm{Al}_{2} \mathrm{O}_{3}$, the radii of $\mathrm{Fe}^{2 x+}$ in $\mathrm{FeO}_{x}$ and $\mathrm{Mn}^{2 y+}$ in $\mathrm{MnO}_{y}$ may be closer to $\mathrm{Ca}^{2+}$ (there is a special example: $\mathrm{Ca}^{2+}: 0.099 \mathrm{~nm}, \mathrm{Mn}^{2+}: 0.091 \mathrm{~nm}$, $\mathrm{Fe}^{2+}: 0.083 \mathrm{~nm}$, and $\left.\mathrm{Mg}^{2+}: 0.078 \mathrm{~nm}, \mathrm{Al}^{3+}: 0.057 \mathrm{~nm}\right)[11,12]$. Therefore, $\mathrm{FeO}_{x}$ and $\mathrm{MnO}_{y}$ may be easier to dissolve in $\mathrm{CaO}$ than $\mathrm{MgO}$ and $\mathrm{Al}_{2} \mathrm{O}_{3}$, and the main compositions dissolved in $\mathrm{f}-\mathrm{CaO}$ were $\mathrm{FeO}_{x}$ and $\mathrm{MnO}_{y}$, but not $\mathrm{MgO}$ and $\mathrm{Al}_{2} \mathrm{O}_{3}$.

The formation mechanism of $\mathrm{f}-\mathrm{CaO}$ was achieved by dissolving $\mathrm{FeO}_{x}$ and $\mathrm{MnO}_{y}$ in $\mathrm{CaO}$ by using high temperature process of steelmaking. So two factors influencing the hydration activity of $\mathrm{f}-\mathrm{CaO}$ in $\mathrm{BOF}$ slag can be considered: the 


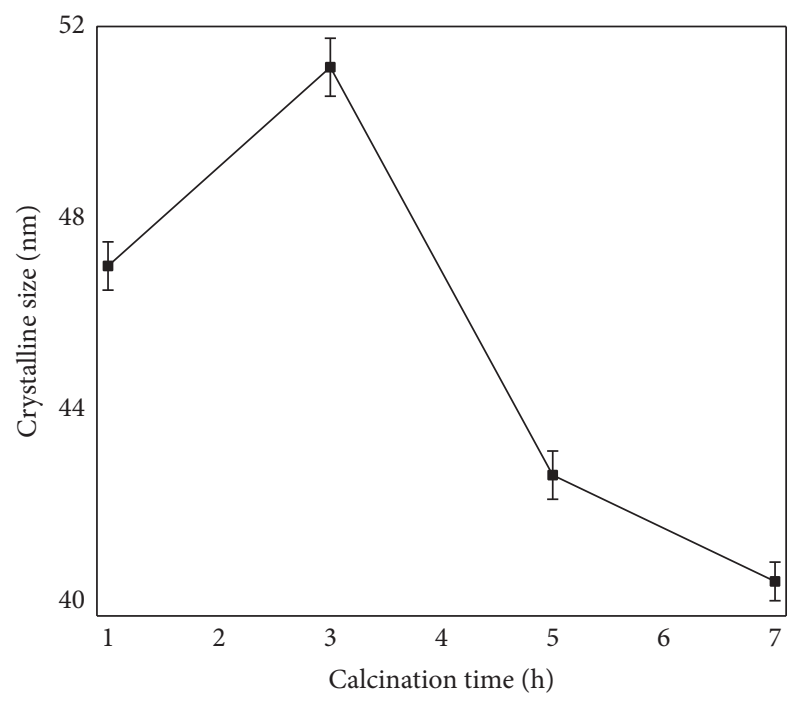

FIGURE 4: Crystalline sizes of monocomponent $\mathrm{f}-\mathrm{CaO}$ calcinated for different times.

duration of the high temperature process and the dissolved $\mathrm{FeO}_{x}$ and $\mathrm{MnO}_{y}$. Since the system of BOF slag is very complex, the influence of these factors on hydration activity of $\mathrm{f}$ $\mathrm{CaO}$ was simply studied through the calcination experiment.

So far, the majority of the published literatures have thought that both $\mathrm{FeO}_{x}$ and $\mathrm{MnO}_{y}$ dissolve in $\mathrm{f}-\mathrm{CaO}[11,12]$, so in the following section, the influence of the duration of the high temperature process and the components of both $\mathrm{FeO}_{x}$ and $\mathrm{MnO}_{y}$ on hydration activity of $\mathrm{f}-\mathrm{CaO}$ was simply studied firstly. If it is necessary, the influence of $\mathrm{FeO}_{x}$ on the hydration activity of $\mathrm{f}-\mathrm{CaO}$ will be further explored in later studies.

F-CaO was divided into two categories: monocomponent $\mathrm{f}-\mathrm{CaO}$ and tricomponent $\mathrm{f}-\mathrm{CaO}$ of $\mathrm{CaO} \cdot a \mathrm{FeO}_{x} \cdot b \mathrm{MnO}_{y}$ system. F-CaO, composed of only $\mathrm{CaO}$, was called monocomponent $\mathrm{f}-\mathrm{CaO}$, and $\mathrm{f}-\mathrm{CaO}$, composed of $\mathrm{CaO}, \mathrm{Fe}_{2} \mathrm{O}_{3}$ and $\mathrm{MnO}_{2}$, was called tricomponent $\mathrm{f}-\mathrm{CaO}$ of $\mathrm{CaO} \cdot a \mathrm{FeO}_{1.5} \cdot b \mathrm{MnO}_{2}$ system. Monocomponent $\mathrm{CaO}$, which is not the same but is similar to monocomponent $\mathrm{f}-\mathrm{CaO}$ in $\mathrm{BOF}$ slag, was prepared to explore the influence mechanisms of the calcination time on the hydration activity of monocomponent $\mathrm{f}-\mathrm{CaO}$, and tricomponent $\mathrm{f}-\mathrm{CaO}$ of $\mathrm{CaO} \cdot a \mathrm{FeO}_{1.5} \cdot b \mathrm{MnO}_{2}$ system, which is not the same but similar to tricomponent $\mathrm{f}-\mathrm{CaO}$ of $\mathrm{CaO} \cdot a \mathrm{FeO}_{x} \cdot b \mathrm{MnO}_{y}$ system in $\mathrm{BOF}$ slag, was prepared to study the influence mechanisms of the dissolved $\mathrm{Fe}_{2} \mathrm{O}_{3}$ and $\mathrm{MnO}_{2}$ on the hydration activity of the tricomponent $\mathrm{f}-\mathrm{CaO}$ of $\mathrm{CaO} \cdot a \mathrm{FeO}_{1.5} \cdot b \mathrm{MnO}_{2}$ system. The aim of this study was to provide useful fundamental knowledge for complex system through studying simplified systems.

\subsection{Microtopography and Hydration Heat Evolution Rate} Curves of Monocomponent $f$-CaO Calcinated for Different Times. Figure 4 shows the crystalline sizes of monocomponent $\mathrm{f}-\mathrm{CaO}$ calcinated for $1,3,5$, and $7 \mathrm{~h}$, and Figure 5 presents their microtopography. With the development of the calcination time, the crystalline sizes of monocomponent f-CaO initially increased but ultimately decreased, and the crystalline size of the monocomponent $\mathrm{f}-\mathrm{CaO}$ calcinated for
$3 \mathrm{~h}$ was $51 \mathrm{~nm}$, which was the largest size. Figure 5 indicates that, compared with monocomponent $\mathrm{f}-\mathrm{CaO}$ calcinated for 1 , 5 , and $7 \mathrm{~h}$, the microtopography of monocomponent $\mathrm{f}-\mathrm{CaO}$ calcinated for $3 \mathrm{~h}$ was more complete and its microstructure was denser. This was probably because the calcination time affects the crystal growth, and the degree of growth will increase with calcination time; however, an unreasonable extension of the calcination time would aggravate secondary recrystallization, which can damage the crystal structure, increasing the number of crystal defects [20].

Figure 6 shows the hydration heat evolution rate curves of monocomponent $\mathrm{f}-\mathrm{CaO}$ calcinated for 1, 3, 5, and $7 \mathrm{~h}$. Figure 6 shows that all of the samples were still not fully hydrated after $3 \mathrm{~h}$. It can be inferred that calcination at $1600^{\circ} \mathrm{C}$ could restrain the hydration activity of $\mathrm{CaO}$ to a certain extent. Compared with monocomponent $\mathrm{f}-\mathrm{CaO}$ calcinated for 1,5 , and $7 \mathrm{~h}$, the hydration heat evolution peaks of monocomponent $\mathrm{f}$ $\mathrm{CaO}$ calcinated for $3 \mathrm{~h}$ fell behind. This was probably because the better the degree of the growth of the crystal, the lower the hydration activity. Figures 4 and 5 show that the crystallinity of monocomponent $\mathrm{f}-\mathrm{CaO}$ calcinated for $3 \mathrm{~h}$ was more complete and its microstructure was denser than those of monocomponent $\mathrm{f}-\mathrm{CaO}$ calcinated for 1,5 , and $7 \mathrm{~h}$.

3.3. Characterization of Simulated Tricomponent $f-\mathrm{CaO}$ of $\mathrm{CaO} \cdot a \mathrm{FeO}{ }_{1.5} \cdot b \mathrm{MnO}_{2}$ System. Figure 3 indicated that the frequency histograms of $\left(n_{\mathrm{Fe}}+n_{\mathrm{Mn}}\right) / n_{\mathrm{Ca}}$ in the calcium iron manganese phase were irregular and varied in different $\mathrm{BOF}$ slags, but Table 2 shows the average contents of $\mathrm{Ca}, \mathrm{Fe}$, and $\mathrm{Mn}$ decreased gradually with the sequence of $\mathrm{Ca}, \mathrm{Fe}$, and $\mathrm{Mn}$, and the average values of $\left(n_{\mathrm{Fe}}+n_{\mathrm{Mn}}\right) / n_{\mathrm{Ca}}$ were about 0.2 . Therefore, the metal oxides compositions of tricomponent $\mathrm{f}-\mathrm{CaO}$ samples were $\mathrm{CaO} \cdot 0.17 \mathrm{FeO}_{1.5} \cdot 0.03 \mathrm{MnO}_{2}$, $\mathrm{CaO} \cdot 0.14 \mathrm{FeO}_{1.5} \cdot 0.06 \mathrm{MnO}_{2}$, and $\mathrm{CaO} \cdot 0.1 \mathrm{FeO}_{1.5} \cdot 0.1 \mathrm{MnO}_{2}$ in this study. To explore the influence mechanisms of dissolved $\mathrm{Fe}_{2} \mathrm{O}_{3}$ and $\mathrm{MnO}_{2}$ on their hydration activity, the following tests were carried out.

3.3.1. XRD Analyses. Figure 7 shows the X-ray diffraction patterns of the three samples of tricomponent $\mathrm{f}$ $\mathrm{CaO}$ of $\mathrm{CaO} \cdot a \mathrm{FeO}_{1.5} \cdot b \mathrm{MnO}_{2}$ system, samples hydrated at $20^{\circ} \mathrm{C}$ for $36 \mathrm{~h}$ and samples autoclaved for $3 \mathrm{~h}$. The phases present in samples $\mathrm{C} \cdot 0.17 \mathrm{~F} \cdot 0.03 \mathrm{M}$ and $\mathrm{C} \cdot 0.14 \mathrm{~F} \cdot 0.06 \mathrm{M}$ were the same, $\mathrm{CaO}, \mathrm{Ca}_{3} \mathrm{Fe}_{1.5} \mathrm{Mn}_{1.5} \mathrm{O}_{8}$, and $\mathrm{Ca}_{2} \mathrm{Fe}_{2} \mathrm{O}_{5}$. After they had hydrated at $20^{\circ} \mathrm{C}$ for $36 \mathrm{~h}$, the detected phases were $\mathrm{Ca}(\mathrm{OH})_{2}, \mathrm{Ca}_{3} \mathrm{Fe}_{1.5} \mathrm{Mn}_{1.5} \mathrm{O}_{8}$, and $\mathrm{Ca}_{2} \mathrm{Fe}_{2} \mathrm{O}_{5}$. After they had been autoclaved for $3 \mathrm{~h}, \mathrm{Ca}(\mathrm{OH})_{2}, \mathrm{Ca}_{3} \mathrm{Fe}_{1.5} \mathrm{Mn}_{1.5} \mathrm{O}_{8}$, $\mathrm{Ca}_{2} \mathrm{Fe}_{2} \mathrm{O}_{5}, \mathrm{FeMnO}_{3}$, and $\mathrm{Fe}_{2} \mathrm{O}_{3}$ were detected in both samples. The phases present in sample $\mathrm{C} \cdot 0.1 \mathrm{~F} \cdot 0.1 \mathrm{M}$ were $\mathrm{CaO}$ and $\mathrm{Ca}_{3} \mathrm{Fe}_{1.5} \mathrm{Mn}_{1.5} \mathrm{O}_{8}$. After it had hydrated at $20^{\circ} \mathrm{C}$ for $36 \mathrm{~h}$, the detected phases were $\mathrm{Ca}(\mathrm{OH})_{2}$ and $\mathrm{Ca}_{3} \mathrm{Fe}_{1.5} \mathrm{Mn}_{1.5} \mathrm{O}_{8}$. After it had been autoclaved for $3 \mathrm{~h}, \mathrm{Ca}(\mathrm{OH})_{2}, \mathrm{Ca}_{3} \mathrm{Fe}_{1.5} \mathrm{Mn}_{1.5} \mathrm{O}_{8}$, and $\mathrm{FeMnO}_{3}$ were detected.

Figure 8 shows the $\mathrm{X}$-ray diffraction patterns of samples $\mathrm{Ca}_{2} \mathrm{Fe}_{2} \mathrm{O}_{5}$ and $\mathrm{Ca}_{3} \mathrm{Fe}_{1.5} \mathrm{Mn}_{1.5} \mathrm{O}_{8}$ and they hydrated at $20^{\circ} \mathrm{C}$ after $28 \mathrm{~d}$. There were no new peaks after $\mathrm{Ca}_{2} \mathrm{Fe}_{2} \mathrm{O}_{5}$ and $\mathrm{Ca}_{3} \mathrm{Fe}_{1.5} \mathrm{Mn}_{1.5} \mathrm{O}_{8}$ were hydrated at $20^{\circ} \mathrm{C}$ for $28 \mathrm{~d}$. This may be because the hydration activity of $\mathrm{Ca}_{2} \mathrm{Fe}_{2} \mathrm{O}_{5}$ and $\mathrm{Ca}_{3} \mathrm{Fe}_{1.5} \mathrm{Mn}_{1.5} \mathrm{O}_{8}$ was so low that $\mathrm{Fe}_{2} \mathrm{O}_{3}$ and $\mathrm{FeMnO}_{3}$ 

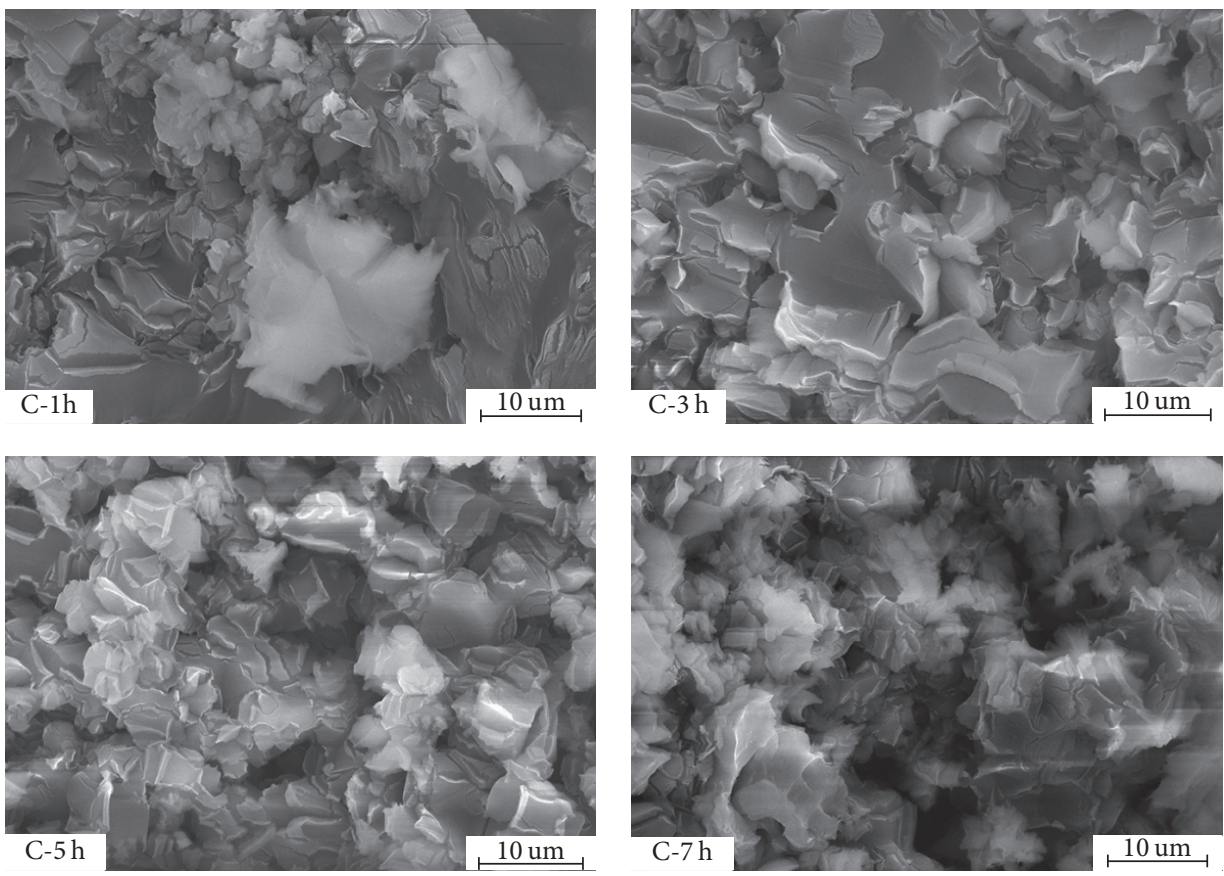

FIGURE 5: SEM images of monocomponent $\mathrm{f}-\mathrm{CaO}$ calcinated for different times.

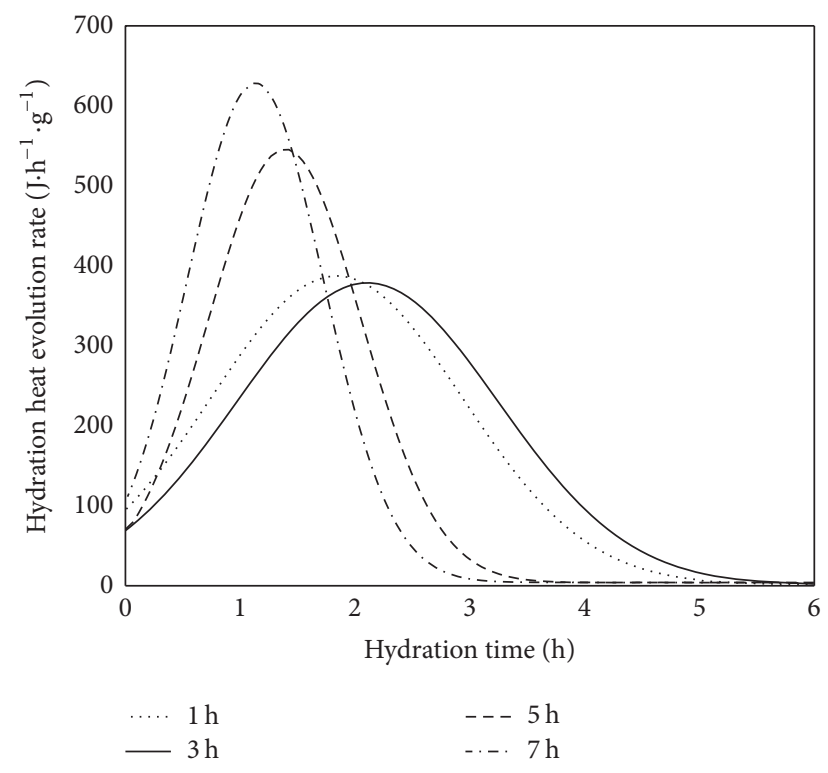

FIGURE 6: Hydration heat evolution rate curves of monocomponent f-CaO calcinated for different times.

contents in their hydration products were less than the detection limit of XRD.

From Figures 7 and 8, it can be concluded that $\mathrm{CaO}$ in the tricomponent $\mathrm{f}-\mathrm{CaO}$ can fully hydrate at $20^{\circ} \mathrm{C}$ after $36 \mathrm{~h}$, even though it went through the calcination at $1600^{\circ} \mathrm{C}$, but $\mathrm{Ca}_{3} \mathrm{Fe}_{1.5} \mathrm{Mn}_{1.5} \mathrm{O}_{8}$ and $\mathrm{Ca}_{2} \mathrm{Fe}_{2} \mathrm{O}_{5}$, which were autoclaved for $3 \mathrm{~h}$, were only slightly hydrated. The hydration activity of both $\mathrm{Ca}_{3} \mathrm{Fe}_{1.5} \mathrm{Mn}_{1.5} \mathrm{O}_{8}$ and $\mathrm{Ca}_{2} \mathrm{Fe}_{2} \mathrm{O}_{5}$ was so low that hydration was undetected at $20^{\circ} \mathrm{C}$ after $28 \mathrm{~d}$. The hydration products of $\mathrm{Ca}_{2} \mathrm{Fe}_{2} \mathrm{O}_{5}$ were $\mathrm{Ca}(\mathrm{OH})_{2}$ and $\mathrm{Fe}_{2} \mathrm{O}_{3}$, and the hydration products of $\mathrm{Ca}_{3} \mathrm{Fe}_{1.5} \mathrm{Mn}_{1.5} \mathrm{O}_{8}$ mainly contained $\mathrm{Ca}(\mathrm{OH})_{2}$ and $\mathrm{FeMnO}_{3} . \mathrm{Ca}_{2} \mathrm{Fe}_{2} \mathrm{O}_{5}$ and $\mathrm{Ca}_{3} \mathrm{Fe}_{1.5} \mathrm{Mn}_{1.5} \mathrm{O}_{8}$ formed by $\mathrm{CaO}$, $\mathrm{Fe}_{2} \mathrm{O}_{3}$, and $\mathrm{MnO}_{2}$ were difficult to hydrate.

Because the hydration reactions occurred in different phases in the tricomponent $\mathrm{f}-\mathrm{CaO}$, the volume expansion rates of the solid phases can be calculated and are presented in Table 3. From Table 3, because of the hydration reactions of $\mathrm{CaO}, \mathrm{Ca}_{2} \mathrm{Fe}_{2} \mathrm{O}_{5}$, and $\mathrm{Ca}_{3} \mathrm{Fe}_{1.5} \mathrm{Mn}_{1.5} \mathrm{O}_{8}$, the volumes of the solid phases increased by $97.88 \%, 43.44 \%$, and $52.02 \%$, respectively. Their volume expansion rates were different, so the volume expansion rates of the tricomponent $\mathrm{f}-\mathrm{CaO}$ varied with different proportions of $\mathrm{CaO}, \mathrm{Ca}_{2} \mathrm{Fe}_{2} \mathrm{O}_{5}$, and $\mathrm{Ca}_{3} \mathrm{Fe}_{1.5} \mathrm{Mn}_{1.5} \mathrm{O}_{8}$.

3.3.2. EDS-Mapping Analyses. Figure 9 shows EDS-mapping of the tricomponent $\mathrm{f}-\mathrm{CaO}$ of $\mathrm{CaO} \cdot a \mathrm{FeO}_{1.5} \cdot b \mathrm{MnO}_{2}$ system. From Figure 7, it can be observed that the main phases in the tricomponent $\mathrm{f}-\mathrm{CaO}$ were $\mathrm{CaO}, \mathrm{Ca}_{3} \mathrm{Fe}_{1.5} \mathrm{Mn}_{1.5} \mathrm{O}_{8}$, and $\mathrm{Ca}_{2} \mathrm{Fe}_{2} \mathrm{O}_{5}$. Figure 9 shows $\mathrm{CaO}$ was widespread, $\mathrm{Ca}_{2} \mathrm{Fe}_{2} \mathrm{O}_{5}$ distributed as dendritic patterns, and $\mathrm{Ca}_{3} \mathrm{Fe}_{1.5} \mathrm{Mn}_{1.5} \mathrm{O}_{8}$ irregularly distributed in the tricomponent $\mathrm{f}-\mathrm{CaO}$. $\mathrm{Ca}_{3} \mathrm{Fe}_{1.5} \mathrm{Mn}_{1.5} \mathrm{O}_{8}$ is distributed with widespread diffusion patterns in $\mathrm{C} \cdot 0.1 \mathrm{~F} \cdot 0.1 \mathrm{M}$ sample.

In order to study the influence of dissolved $\mathrm{Fe}_{2} \mathrm{O}_{3}$ and $\mathrm{MnO}_{2}$ on the hydration activity of the tricomponent $\mathrm{f}-\mathrm{CaO}$ of $\mathrm{CaO} \cdot a \mathrm{FeO}_{1.5} \cdot b \mathrm{MnO}_{2}$ system, except for $\mathrm{Ca}_{2} \mathrm{Fe}_{2} \mathrm{O}_{5}$ and $\mathrm{Ca}_{3} \mathrm{Fe}_{1.5} \mathrm{Mn}_{1.5} \mathrm{O}_{8}$ in the tricomponent $\mathrm{f}-\mathrm{CaO}$ that were hard to hydrate, the hydration activity of $\mathrm{CaO}$ in tricomponent $\mathrm{f}$ $\mathrm{CaO}$ should also be investigated. It is meaningful to identify whether and how the distribution of the patterns of $\mathrm{Ca}_{2} \mathrm{Fe}_{2} \mathrm{O}_{5}$ and $\mathrm{Ca}_{3} \mathrm{Fe}_{1.5} \mathrm{Mn}_{1.5} \mathrm{O}_{8}$ influenced the hydration activity of $\mathrm{CaO}$ in the tricomponent $\mathrm{f}-\mathrm{CaO}$. 


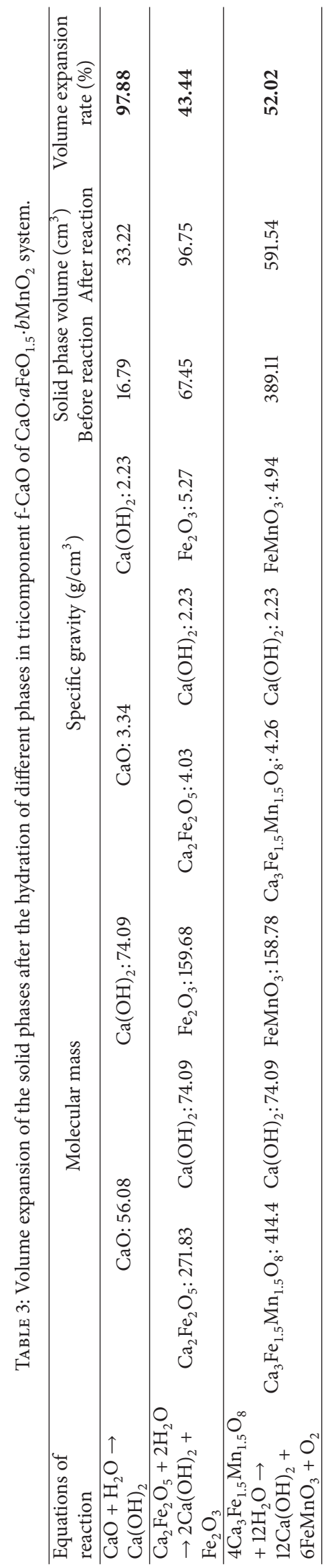



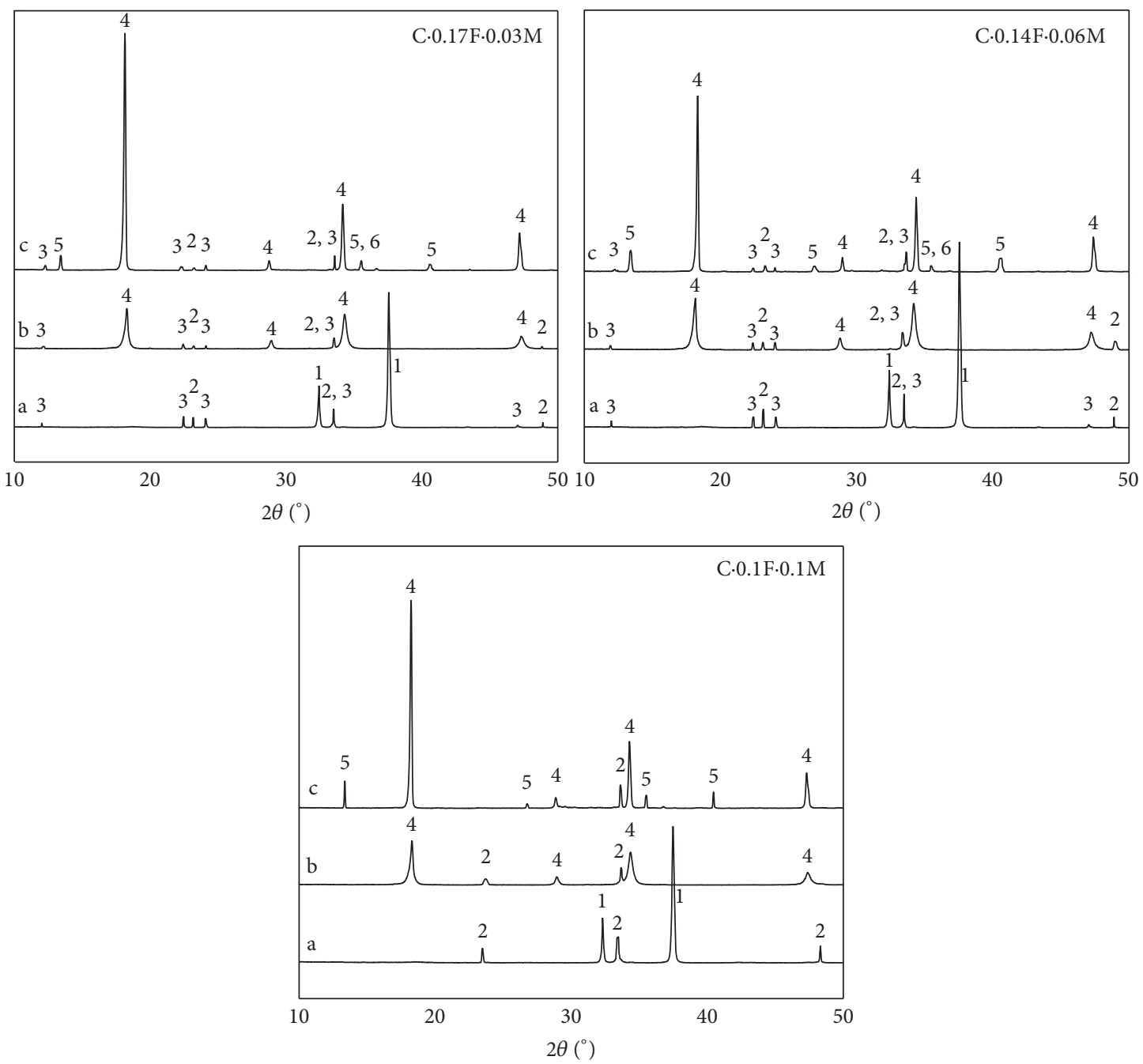
(1) $\mathrm{CaO}$
(4) $\mathrm{Ca}(\mathrm{OH})_{2}$
(2) $\mathrm{Ca}_{3} \mathrm{Fe}_{1.5} \mathrm{Mn}_{1.5} \mathrm{O}_{8}$
(5) $\mathrm{FeMnO}_{3}$
(3) $\mathrm{Ca}_{2} \mathrm{Fe}_{2} \mathrm{O}_{5}$
(6) $\mathrm{Fe}_{2} \mathrm{O}_{3}$

Figure 7: X-ray diffraction patterns of tricomponent $\mathrm{f}-\mathrm{CaO}$ of $\mathrm{CaO} \cdot a \mathrm{FeO}_{1.5} \cdot b \mathrm{MnO}_{2}$ system and their hydration products under different hydration conditions (a: no hydration, b: hydration at $20^{\circ} \mathrm{C}$ for $36 \mathrm{~h}$, and c: autoclave hydration for $3 \mathrm{~h}$ ).

3.3.3. Hydration Heat Evolution Analyses. The increasing curves shown in Figure 10 are the cumulative hydration heat curves of the monocomponent $\mathrm{f}-\mathrm{CaO}$ and tricomponent $\mathrm{f}-\mathrm{CaO}$ of $\mathrm{CaO} \cdot a \mathrm{FeO}_{1.5} \cdot b \mathrm{MnO}_{2}$ system. There were no increases in the cumulative hydration heats of C.0.17F.0.03M, $\mathrm{C} \cdot 0.14 \mathrm{~F} \cdot 0.06 \mathrm{M}$, and $\mathrm{C} \cdot 0.1 \mathrm{~F} \cdot 0.1 \mathrm{M}$ after $30 \mathrm{~h}$, and the cumulative hydration heats of them were similar after $30 \mathrm{~h}$. When their initial masses were $0.6 \mathrm{~g}$, the contents, expressed by the amount of substance with different compositions, could be calculated as shown in Table 4. Table 4 shows the $\mathrm{CaO}$ contents related to $\mathrm{C} \cdot 0.17 \mathrm{~F} \cdot 0.03 \mathrm{M}, \mathrm{C} \cdot 0.14 \mathrm{~F} \cdot 0.06 \mathrm{M}$, and $\mathrm{C} \cdot 0.1 \mathrm{~F} \cdot 0.1 \mathrm{M}$ being $0.0064,0.0061$, and $0.0057 \mathrm{~mol}$, respectively. It was clear that their $\mathrm{CaO}$ contents were similar. Since $\mathrm{CaO}$ was totally hydrated, but no hydration was detected in $\mathrm{Ca}_{2} \mathrm{Fe}_{2} \mathrm{O}_{5}$ and $\mathrm{Ca}_{3} \mathrm{Fe}_{1.5} \mathrm{Mn}_{1.5} \mathrm{O}_{8}$ when the tricomponent $\mathrm{f}$ $\mathrm{CaO}$ took part in the hydration process at room temperature within a short time, the final cumulative hydration heat of $\mathrm{C} \cdot 0.17 \mathrm{~F} \cdot 0.03 \mathrm{M}, \mathrm{C} \cdot 0.14 \mathrm{~F} \cdot 0.06 \mathrm{M}$, and $\mathrm{C} \cdot 0.1 \mathrm{~F} \cdot 0.1 \mathrm{M}$ was similar.

The single peak type curves shown in Figure 10 are the hydration heat evolution rate curves of monocomponent $\mathrm{f}-\mathrm{CaO}$ and tricomponent $\mathrm{f}-\mathrm{CaO}$ of $\mathrm{CaO} \cdot a \mathrm{FeO}_{1.5} \cdot b \mathrm{MnO}_{2}$ system. Compared with the narrow and high hydration heat evolution peak of monocomponent $\mathrm{f}-\mathrm{CaO}$, the hydration heat evolution peaks of the tricomponent $\mathrm{f}-\mathrm{CaO}$ were wide and low. Compared with monocomponent $\mathrm{f}-\mathrm{CaO}$, the hydration heat evolution peaks of tricomponent $\mathrm{f}-\mathrm{CaO}$ fell slightly behind, and the larger the $b / a$ was, the further its hydration heat evolution peak fell behind. It is clearly indicated that, compared with monocomponent $\mathrm{f}-\mathrm{CaO}$, the hydration activity of $\mathrm{CaO}$ in the tricomponent $\mathrm{f}-\mathrm{CaO}$ decreased continuously with increasing $b / a$. When the contact of $\mathrm{CaO}$ and $\mathrm{H}_{2} \mathrm{O}$ became more difficult, the hydration activity of $\mathrm{CaO}$ reduced 
TABLE 4: The compositions of tricomponent $\mathrm{f}-\mathrm{CaO}$ of $\mathrm{CaO} \cdot a \mathrm{FeO}_{1.5} \cdot b \mathrm{MnO}_{2}$ system.

\begin{tabular}{|c|c|c|c|c|c|c|c|c|}
\hline Tricomponent f-CaO & \multicolumn{3}{|c|}{$\mathrm{CaO} \cdot 0.17 \mathrm{FeO}_{1.5} \cdot 0.03 \mathrm{MnO}_{2}$} & \multicolumn{3}{|c|}{$\mathrm{CaO} \cdot 0.14 \mathrm{FeO}_{1.5} \cdot 0.06 \mathrm{MnO}_{2}$} & \multicolumn{2}{|c|}{$\mathrm{CaO} \cdot 0.1 \mathrm{FeO}_{1.5} \cdot 0.1 \mathrm{MnO}_{2}$} \\
\hline Mass $(\mathrm{g})$ & & & & \multicolumn{3}{|c|}{0.6} & \\
\hline molecular mass & \multicolumn{3}{|c|}{72.26} & \multirow{2}{*}{\multicolumn{3}{|c|}{$\begin{array}{c}72.47 \\
0.0083\end{array}$}} & \multicolumn{2}{|l|}{72.76} \\
\hline Amount of substance (mol) & \multicolumn{3}{|c|}{0.0083} & & & & 0.0082 & \\
\hline Phase composition & $\mathrm{Ca}_{3} \mathrm{Fe}_{1.5} \mathrm{Mn}_{1.5} \mathrm{O}_{8}$ & $\mathrm{Ca}_{2} \mathrm{Fe}_{2} \mathrm{O}_{5}$ & $\mathrm{CaO}$ & $\mathrm{Ca}_{3} \mathrm{Fe}_{1.5} \mathrm{Mn}_{1.5} \mathrm{O}_{8}$ & $\mathrm{Ca}_{2} \mathrm{Fe}_{2} \mathrm{O}_{5}$ & $\mathrm{CaO}$ & $\mathrm{Ca}_{3} \mathrm{Fe}_{1.5} \mathrm{Mn}_{1.5} \mathrm{O}_{8}$ & $\mathrm{CaO}$ \\
\hline Amount of substance (mol) & 0.0002 & 0.0006 & 0.0064 & 0.0005 & 0.0003 & 0.0061 & 0.0008 & 0.0057 \\
\hline
\end{tabular}

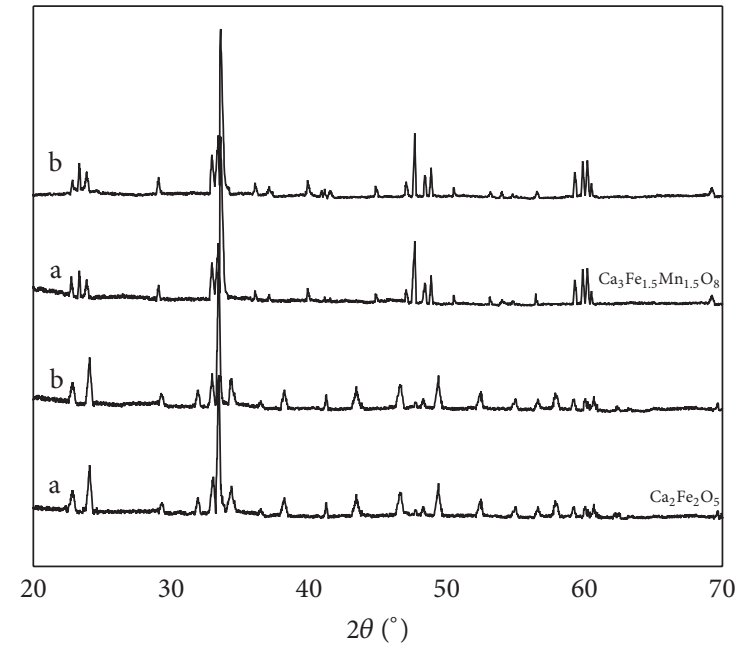

FIGURE 8: X-ray diffraction patterns of $\mathrm{Ca}_{2} \mathrm{Fe}_{2} \mathrm{O}_{5}, \mathrm{Ca}_{3} \mathrm{Fe}_{1.5} \mathrm{Mn}_{1.5} \mathrm{O}_{8}$, and their hydration products (a: no hydration and b: hydration at $20^{\circ} \mathrm{C}$ for $28 \mathrm{~d}$ ).

[21], so it may be that the distribution patterns of $\mathrm{Ca}_{2} \mathrm{Fe}_{2} \mathrm{O}_{5}$ and $\mathrm{Ca}_{3} \mathrm{Fe}_{1.5} \mathrm{Mn}_{1.5} \mathrm{O}_{8}$ in tricomponent $\mathrm{f}-\mathrm{CaO}$ can restrain the contact between $\mathrm{CaO}$ and $\mathrm{H}_{2} \mathrm{O}$ in the hydration process of tricomponent $\mathrm{f}-\mathrm{CaO}$; the effect became more serious with increasing $\mathrm{Ca}_{3} \mathrm{Fe}_{1.5} \mathrm{Mn}_{1.5} \mathrm{O}_{8}$ contents and decreasing of $\mathrm{Ca}_{2} \mathrm{Fe}_{2} \mathrm{O}_{5}$ contents. Combined with the analyses of Figure 7, the sequence of the hydration activity of monocomponent f-CaO and tricomponent f-CaO was as follows: $\mathrm{Ca}_{2} \mathrm{Fe}_{2} \mathrm{O}_{5}$ and $\mathrm{Ca}_{3} \mathrm{Fe}_{1.5} \mathrm{Mn}_{1.5} \mathrm{O}_{8}$ in tricomponent $\mathrm{f}-\mathrm{CaO}<\mathrm{CaO}$ in tricomponent $\mathrm{f}-\mathrm{CaO}<$ monocomponent $\mathrm{f}-\mathrm{CaO}$.

Since simulated monocomponent $\mathrm{CaO}$ and tricomponent $\mathrm{f}-\mathrm{CaO}$ of $\mathrm{CaO} \cdot a \mathrm{FeO}_{1.5} \cdot b \mathrm{MnO}_{2}$ system in this study are similar to monocomponent $\mathrm{f}-\mathrm{CaO}$ and tricomponent $\mathrm{f}-\mathrm{CaO}$ of $\mathrm{CaO} \cdot a \mathrm{FeO}_{x} \cdot b \mathrm{MnO}_{y}$ system in $\mathrm{BOF}$ slag, the conclusions of this study can be extended to monocomponent $\mathrm{f}-\mathrm{CaO}$ and tricomponent $\mathrm{f}-\mathrm{CaO}$ of $\mathrm{CaO} \cdot a \mathrm{FeO}_{x} \cdot b \mathrm{MnO}_{y}$ system in $\mathrm{BOF}$ slag. The following deductions can be made: (i) the volume expansion rates of tricomponent $\mathrm{f}-\mathrm{CaO}$ of $\mathrm{CaO} \cdot a \mathrm{FeO}_{x}$ .$b \mathrm{MnO}_{y}$ system in $\mathrm{BOF}$ slag, due to the different volume expansion rates of $\mathrm{CaO}$ and solid solutions $\mathrm{CaO}-\mathrm{FeO}_{x}$ and $\mathrm{CaO}-\mathrm{FeO}_{x}-\mathrm{MnO}_{y}$, varied with different proportions of $\mathrm{CaO}$ and solid solutions $\mathrm{CaO}-\mathrm{FeO}_{x}$ and $\mathrm{CaO}-\mathrm{FeO}_{x}-\mathrm{MnO}_{y}$, which was different from the current view that the volume expansion rate, due to $\mathrm{f}-\mathrm{CaO}$ hydration, is merely $97.88 \%$ [8]; this study showed that $97.88 \%$ was only suitable for monocomponent $\mathrm{f}-\mathrm{CaO}$; (ii) in $\mathrm{BOF}$ slag, the sequence of the hydration activity of monocomponent $\mathrm{f}-\mathrm{CaO}$ and tricomponent $\mathrm{f}-\mathrm{CaO}$ of $\mathrm{CaO} \cdot a \mathrm{FeO}_{x} \cdot b \mathrm{MnO}_{y}$ system should be solid solutions $\mathrm{CaO}-\mathrm{FeO}_{x}$ and $\mathrm{CaO}-\mathrm{FeO}_{x}-\mathrm{MnO}_{y}$ in tricomponent $\mathrm{f}-\mathrm{CaO}<$ $\mathrm{CaO}$ in tricomponent $\mathrm{f}-\mathrm{CaO}<$ monocomponent $\mathrm{f}-\mathrm{CaO}$; (iii) monocomponent $\mathrm{f}-\mathrm{CaO}$ and $\mathrm{CaO}$ in tricomponent $\mathrm{f}-\mathrm{CaO}$ of $\mathrm{CaO} \cdot a \mathrm{FeO}_{x} \cdot b \mathrm{MnO}_{y}$ system, which underwent calcination at $1600^{\circ} \mathrm{C}$, could hydrate fully in the hydration process at room temperature within a short time, but solid solutions $\mathrm{CaO}-\mathrm{FeO}_{x}$ and $\mathrm{CaO}-\mathrm{FeO}_{x}-\mathrm{MnO}_{y}$ were hard to hydrate. In the following section, the reason why solid solutions $\mathrm{CaO}-\mathrm{FeO}_{x}$ and $\mathrm{CaO}-\mathrm{FeO}_{x}-\mathrm{MnO}_{y}$ in tricomponent $\mathrm{f}-\mathrm{CaO}$ in $\mathrm{BOF}$ slag were hard to hydrate was explained by theoretical analysis.

\section{Theoretical Analysis of the Reason Why the Solid Solutions $\mathrm{CaO}-\mathrm{FeO}_{x}$ and

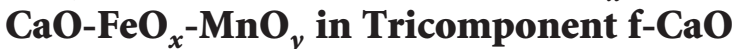 Were Hard to Hydrate}

$\mathrm{AO}_{n}, \mathrm{BO}_{m}$, and $\mathrm{A}(\mathrm{OH})_{2 n}$ were used to represent metal oxides and the hydration product, and (1) and (2) represent the hydration reaction of $\mathrm{AO}_{n}$ and the solid solution reaction of $\mathrm{AO}_{n}$ and $\mathrm{BO}_{m}$, separately.

$$
\begin{gathered}
\mathrm{AO}_{n}+n \mathrm{H}_{2} \mathrm{O} \longrightarrow \mathrm{A}(\mathrm{OH})_{2 n}, \quad \Delta_{r} G_{m, \mathrm{~A}}^{\theta} \\
x \mathrm{AO}_{n}+y \mathrm{BO}_{m} \longrightarrow x \mathrm{AO}_{n}-y \mathrm{BO}_{m}, \quad \Delta_{r} G_{m}^{\theta},
\end{gathered}
$$

where $x \mathrm{AO}_{n}-y \mathrm{BO}_{m}, \Delta_{f} G_{m}^{\theta}, \Delta_{r} G_{m}^{\theta}$, and $\left(\partial \Delta_{r} G_{m}^{\theta} / \partial x\right)_{y}$ represent bicomponent metal oxide solid solution with a certain proportion of $x / y$, standard molar formation Gibbs function, standard molar reaction Gibbs function, and partial molar quantity of standard molar reaction Gibbs function of bicomponent metal oxide solid solution, respectively.

The hydration of $x \mathrm{AO}_{n}-y \mathrm{BO}_{m}$ gradually proceeded. The first stage was associated with the hydration of $\mathrm{AO}_{n}$ whose hydration activity was higher than that of $\mathrm{BO}_{m}$. The hydration reaction of this stage is described by

$$
x \mathrm{AO}_{n}-y \mathrm{BO}_{m}+n x \mathrm{H}_{2} \mathrm{O} \longrightarrow x \mathrm{~A}(\mathrm{OH})_{2 n}+y \mathrm{BO}_{m} .
$$

The second stage was related to the hydration of $\mathrm{BO}_{m}$ if its hydration was possible. The hydration reaction of this stage is described by

$$
\mathrm{BO}_{m}+m \mathrm{H}_{2} \mathrm{O} \longrightarrow \mathrm{B}(\mathrm{OH})_{2 m} .
$$

The overall hydration reaction of $x \mathrm{AO}_{n}-y \mathrm{BO}_{m}$ was as follows:

$$
\begin{gathered}
x \mathrm{AO}_{n}-y \mathrm{BO}_{m}+(n x+m y) \mathrm{H}_{2} \mathrm{O} \\
\longrightarrow x \mathrm{~A}(\mathrm{OH})_{2 n}+y \mathrm{~B}(\mathrm{OH})_{2 m} .
\end{gathered}
$$



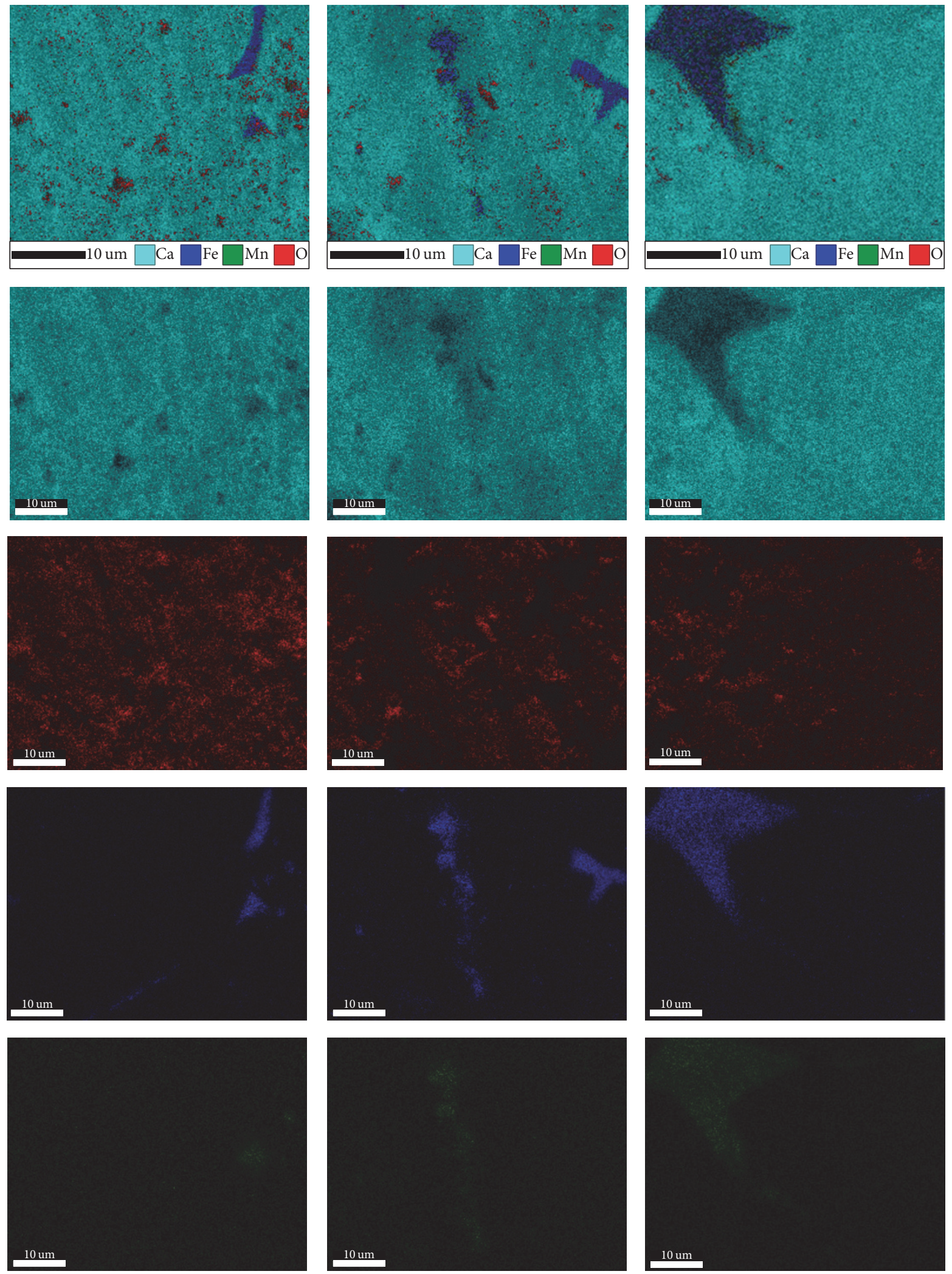

$a=0.17, b=0.03$

$a=0.14, b=0.06$

$a=0.1, b=0.1$

Figure 9: EDS-mapping images of fractured tricomponent $\mathrm{f}-\mathrm{CaO}$ of $\mathrm{CaO} \cdot a \mathrm{FeO}_{1.5} \cdot b \mathrm{MnO}_{2}$ system. 


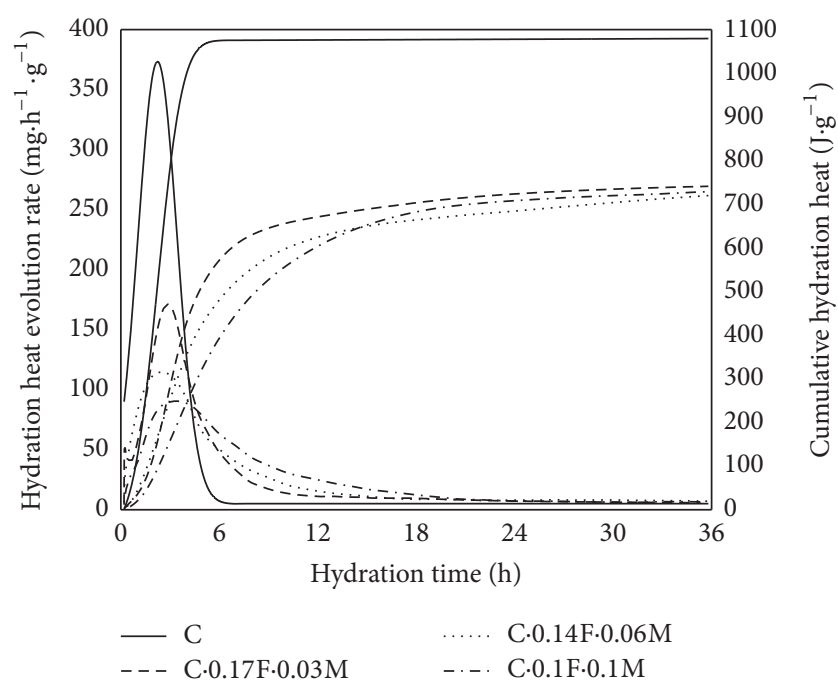

FIgURE 10: Hydration heat curves of monocomponent $\mathrm{f}-\mathrm{CaO}$ and tricomponent $\mathrm{f}-\mathrm{CaO}$ of $\mathrm{CaO} \cdot a \mathrm{FeO}_{1.5} \cdot b \mathrm{MnO}_{2}$ system.

For first stage, the hydration of $\mathrm{AO}_{n}$ in $x \mathrm{AO}_{n}-y \mathrm{BO}_{m}$ can be classified into two types.

The first type was related to the fact that all $\mathrm{AO}_{n}$ in $x \mathrm{AO}_{n}-y \mathrm{BO}_{m}$ took part in hydration reaction. The hydration reaction was as follows:

$$
\begin{aligned}
x \mathrm{AO}_{n}-y \mathrm{BO}_{m}+n x \mathrm{H}_{2} \mathrm{O} \longrightarrow x \mathrm{~A}(\mathrm{OH})_{2 n}+ & y \mathrm{BO}_{m}, \\
& \Delta_{r} G_{m, \mathrm{~A}(\text { mix })}^{\theta} .
\end{aligned}
$$

After calculation,

$$
\begin{aligned}
\Delta_{r} G_{m, \mathrm{~A}(\mathrm{mix})}^{\theta}= & \sum_{\mathrm{C}} \nu_{\mathrm{C}} \Delta_{f} G_{m}^{\theta}(\mathrm{C}) \\
= & y \Delta_{f} G_{m}^{\theta}\left(\mathrm{BO}_{m}\right)+x \Delta_{f} G_{m}^{\theta}\left(\mathrm{A}(\mathrm{OH})_{2 n}\right) \\
& -n x \Delta_{f} G_{m}^{\theta}\left(\mathrm{H}_{2} \mathrm{O}\right) \\
& -\Delta_{f} G_{m}^{\theta}\left(x \mathrm{AO}_{n}-y \mathrm{BO}_{m}\right) \\
= & x \Delta_{r} G_{m, \mathrm{~A}}^{\theta}-\Delta_{r} G_{m}^{\theta} .
\end{aligned}
$$

So (8) showed the standard molar reaction Gibbs function of the hydration reaction of $\mathrm{AO}_{n}$ in $x \mathrm{AO}_{n}-y \mathrm{BO}_{m}$ for this type.

$$
\Delta_{r} G_{m, \mathrm{~A}(\mathrm{mix}, 1)}^{\theta}=\Delta_{r} G_{m, \mathrm{~A}}^{\theta}-\frac{\Delta_{r} G_{m}^{\theta}}{x} .
$$

The second type was associated with the fact that part of $\mathrm{AO}_{n}$ in $x \mathrm{AO}_{n}-y \mathrm{BO}_{m}$ took part in hydration reaction. The hydration reaction was expressed as

$$
\begin{aligned}
& x \mathrm{AO}_{n}-y \mathrm{BO}_{m}+n d x \mathrm{H}_{2} \mathrm{O} \\
& \longrightarrow d x \mathrm{~A}(\mathrm{OH})_{2 n}+(x-d x) \mathrm{AO}_{n}-y \mathrm{BO}_{m}, \\
& \qquad \Delta_{r} G_{m, \mathrm{~A}(d)}^{\theta} .
\end{aligned}
$$

After calculation,

$$
\begin{aligned}
\Delta_{r} G_{m, \mathrm{~A}(d)}^{\theta}= & \sum_{\mathrm{C}} v_{\mathrm{C}} \Delta_{f} G_{m}^{\theta}(\mathrm{C}) \\
= & \Delta_{f} G_{m}^{\theta}\left((x-d x) \mathrm{AO}_{n}-y \mathrm{BO}_{m}\right) \\
& +d x \Delta_{f} G_{m}^{\theta}\left(\mathrm{A}(\mathrm{OH})_{2 n}\right) \\
& -n d x \Delta_{f} G_{m}^{\theta}\left(\mathrm{H}_{2} \mathrm{O}\right) \\
& -\Delta_{f} G_{m}^{\theta}\left(x \mathrm{AO}_{n}-y \mathrm{BO}_{m}\right) .
\end{aligned}
$$

So (11) showed the standard molar reaction Gibbs function of the hydration reaction of $\mathrm{AO}_{n}$ in $x \mathrm{AO}_{n}-y \mathrm{BO}_{m}$ for this type.

$$
\Delta_{r} G_{m, \mathrm{~A}(d, 1)}^{\theta}=-\left(\frac{\partial \Delta_{r} G_{m}^{\theta}}{\partial x}\right)_{y}+\Delta_{r} G_{m, \mathrm{~A}}^{\theta} .
$$

In general, the values of $\Delta_{r} G_{m}^{\theta}$ and $\left(\partial \Delta_{r} G_{m}^{\theta} / \partial x\right)_{y}$ of the bicomponent metal oxide solid solution are negative [22]. It can be deduced that whether all or part of $\mathrm{AO}_{n}$ in $x \mathrm{AO}_{n^{-}}$ $y \mathrm{BO}_{m}$ took part in the first stage of the hydration of $x \mathrm{AO}_{n^{-}}$ $y \mathrm{BO}_{m}$, the absolute values of $\Delta_{r} G_{m, \mathrm{~A}(\mathrm{mix}, 1)}^{\theta}$ and $\Delta_{r} G_{m, \mathrm{~A}(d, 1)}^{\theta}$ both were smaller than the absolute value of $\Delta_{r} G_{m, \mathrm{~A}}^{\theta}$ of the hydration reaction of $\mathrm{AO}_{n}$ alone. It can be speculated that the first stage of the hydration of $x \mathrm{AO}_{n}-y \mathrm{BO}_{m}$ was more difficult than the hydration of $\mathrm{AO}_{n}$ alone, so the overall hydration of $x \mathrm{AO}_{n}-y \mathrm{BO}_{m}$ must be more difficult than that of $\mathrm{AO}_{n}$ alone. Tricomponent metal oxide solid solution $x \mathrm{AO}_{n}-y \mathrm{BO}_{m}-z \mathrm{CO}_{k}$ was the product of the solid solution reaction among $\mathrm{AO}_{n}$, $\mathrm{BO}_{m}$, and $\mathrm{CO}_{k}$ with a certain proportion of $x / y / z$. Tricomponent metal oxide solid solution $x \mathrm{AO}_{n}-y \mathrm{BO}_{m}-z \mathrm{CO}_{k}$ can be seen as a pseudo-bi-component metal oxide solid solution of $\mathrm{AO}_{n}$ and $y \mathrm{BO}_{m}-z \mathrm{CO}_{k}$ with a proportion of $x / 1$. If the values of $\Delta_{r} G_{m}^{\theta}$ and $\left(\partial \Delta_{r} G_{m}^{\theta} / \partial x\right)_{y, z}$ of pseudo-bi-component metal oxide solid solution $x \mathrm{AO}_{n}-y \mathrm{BO}_{m}-z \mathrm{CO}_{k}$ were still negative, its hydration must also be more difficult than that of $\mathrm{AO}_{n}$ alone. Therefore, there was the possibility that solid solutions $\mathrm{CaO}-\mathrm{FeO}_{x}$ and $\mathrm{CaO}-\mathrm{FeO}-\mathrm{MnO}_{y}$ in tricomponent $\mathrm{f}-\mathrm{CaO}$ in BOF slag were difficult to hydrate because of the decreased hydration reaction driving force, namely, the absolute value of standard molar reaction Gibbs function.

This study indicated that only solid solutions $\mathrm{CaO}-\mathrm{FeO}_{x}$ and $\mathrm{CaO}-\mathrm{FeO}_{x}-\mathrm{MnO}_{y}$ in tricomponent $\mathrm{f}-\mathrm{CaO}$ were hard to hydrate, and their hydration activity was very low. Therefore, if $\mathrm{f}-\mathrm{CaO}$ can make contact with $\mathrm{H}_{2} \mathrm{O}$ during the hydration process of CBS, all of the monocomponent $\mathrm{f}-\mathrm{CaO}$ and $\mathrm{CaO}$ in tricomponent $\mathrm{f}-\mathrm{CaO}$ of $\mathrm{CaO} \cdot a \mathrm{FeO}_{x} \cdot b \mathrm{MnO}_{y}$ system undergo hydration within a short time, which will not lead to a volume expansion of BOF slag after the CBS hardens; however, solid solutions $\mathrm{CaO}-\mathrm{FeO}_{x}$ and $\mathrm{CaO}-\mathrm{FeO}{ }_{x}-\mathrm{MnO}_{y}$ will continue to slowly hydrate after the CBS hardens, resulting in the volume expansion. 


\section{Conclusions}

The following conclusions can be drawn from the test results and discussion.

In $\mathrm{BOF}$ slag, $\mathrm{f}-\mathrm{CaO}$ included at least the calcium iron phase and calcium iron manganese phase whose compositions were diverse. The reason why $\mathrm{f}-\mathrm{CaO}$ had different compositions was that different compositions of $\mathrm{f}-\mathrm{CaO}$ were found in different phases.

Simulated experiment indicated that high temperature calcination can restrain the hydration activity of $\mathrm{CaO}$. Since the volume expansion rates of $\mathrm{CaO}, \mathrm{Ca}_{2} \mathrm{Fe}_{2} \mathrm{O}_{5}$, and $\mathrm{Ca}_{3} \mathrm{Fe}_{1.5} \mathrm{Mn}_{1.5} \mathrm{O}_{8}$ in tricomponent $\mathrm{f}-\mathrm{CaO}$ of $\mathrm{CaO} \cdot a \mathrm{FeO}_{1.5}$ . $b \mathrm{MnO}_{2}$ system were $97.88 \%, 43.44 \%$, and $52.02 \%$, respectively, the volume expansion rates of tricomponent $\mathrm{f}-\mathrm{CaO}$ varied with different proportions of $\mathrm{CaO}, \mathrm{Ca}_{2} \mathrm{Fe}_{2} \mathrm{O}_{5}$, and $\mathrm{Ca}_{3} \mathrm{Fe}_{1.5} \mathrm{Mn}_{1.5} \mathrm{O}_{8}$. The hydration activity sequence was as $\mathrm{Ca}_{2} \mathrm{Fe}_{2} \mathrm{O}_{5}$ and $\mathrm{Ca}_{3} \mathrm{Fe}_{1.5} \mathrm{Mn}_{1.5} \mathrm{O}_{8}$ in tricomponent $\mathrm{f}-\mathrm{CaO}$ $<\mathrm{CaO}$ in tricomponent $\mathrm{f}-\mathrm{CaO}<$ mono-component $\mathrm{f}$ $\mathrm{CaO}$. Monocomponent $\mathrm{f}-\mathrm{CaO}$ and $\mathrm{CaO}$ in tricomponent $\mathrm{f}-$ $\mathrm{CaO}$ of $\mathrm{CaO} \cdot a \mathrm{FeO}_{1.5} \cdot b \mathrm{MnO}_{2}$ system can hydrate fully at room temperature within a short time, but $\mathrm{Ca}_{2} \mathrm{Fe}_{2} \mathrm{O}_{5}$ and $\mathrm{Ca}_{3} \mathrm{Fe}_{1.5} \mathrm{Mn}_{1.5} \mathrm{O}_{8}$ were difficult to hydrate.

In BOF slag, the volume expansion rates of tricomponent $\mathrm{f}-\mathrm{CaO}$ of $\mathrm{CaO} \cdot a \mathrm{FeO}_{x} \cdot b \mathrm{MnO}_{y}$ system changed with different proportions of $\mathrm{CaO}$ and solid solutions $\mathrm{CaO}-\mathrm{FeO}_{x}$ and $\mathrm{CaO}-\mathrm{FeO}_{x}-\mathrm{MnO}_{y}$. The hydration activity sequence of monocomponent $\mathrm{f}-\mathrm{CaO}$ and tricomponent $\mathrm{f}-\mathrm{CaO}$ of $\mathrm{CaO} \cdot a \mathrm{FeO}_{x}$ $\cdot b \mathrm{MnO}_{y}$ system was solid solutions $\mathrm{CaO}-\mathrm{FeO}_{x}$ and $\mathrm{CaO}-$ $\mathrm{FeO}_{x}-\mathrm{MnO}_{y}$ in tricomponent $\mathrm{f}-\mathrm{CaO}<\mathrm{CaO}$ in tricomponent $\mathrm{f}-\mathrm{CaO}<$ monocomponent $\mathrm{f}-\mathrm{CaO}$. If $\mathrm{f}-\mathrm{CaO}$ can make contact with $\mathrm{H}_{2} \mathrm{O}$ during the hydration process of CBS, only $\mathrm{CaO}-\mathrm{FeO}_{x}$ and $\mathrm{CaO}-\mathrm{FeO}_{x}-\mathrm{MnO}_{y}$ in bicomponent $\mathrm{f}$ $\mathrm{CaO}$, due to its low hydration activity, will lead to volume expansion after the CBS hardens. The reason why solid solutions $\mathrm{CaO}-\mathrm{FeO}_{x}$ and $\mathrm{CaO}-\mathrm{FeO}{ }_{x}-\mathrm{MnO}_{y}$ were difficult to hydrate was that their hydration reaction driving force, the absolute value of standard molar reaction Gibbs function, decreased.

\section{Competing Interests}

The authors declare that there is no conflict of interests regarding the publication of this paper.

\section{Acknowledgments}

The authors acknowledge the support from National Natural Science Foundation of China (Grant no. 51174011) and the Research Fund of Collaborative Innovation Center for Ecological Building Materials and Environmental Protection Equipments (Grant no. YCXT201613).

\section{References}

[1] F. H. Han, Z. Q. Zhang, D. M. Wang, and P. Yan, "Hydration heat evolution and kinetics of blended cement containing steel slag at different temperatures," Thermochimica Acta, vol. 605, pp. 4351, 2015.
[2] Opsteel.cn, "Analysis of steel production through diagram," 2015, http://www.opsteel.cn/news/2015-01/ 0DBFD459DAF8413DE050080A7DC97F83.html.

[3] H. Yi, G. P. Xu, and H. G. Cheng, "An overview of utilization of steel slag," Procedia Environmental Sciences, vol. 16, pp. 791-801, 2012.

[4] W. Chen, J. Hong, and C. Xu, "Pollutants generated by cement production in China, their impacts, and the potential for environmental improvement," Journal of Cleaner Production, vol. 103, pp. 61-69, 2015.

[5] Q. Wang, J. W. Yang, and P. Y. Yan, "Influence of initial alkalinity on the hydration of steel slag," Science China Technological Sciences, vol. 55, no. 12, pp. 3378-3387, 2012.

[6] Q. Wang and P. Yan, "Hydration properties of basic oxygen furnace steel slag," Construction and Building Materials, vol. 24, no. 7, pp. 1134-1140, 2010.

[7] Q. Wang, P. Yan, J. Yang, and B. Zhang, "Influence of steel slag on mechanical properties and durability of concrete," Construction and Building Materials, vol. 47, pp. 1414-1420, 2013.

[8] G. Wang, Y. Wang, and Z. Gao, "Use of steel slag as a granular material: volume expansion prediction and usability criteria," Journal of Hazardous Materials, vol. 184, no. 1-3, pp. 555-560, 2010.

[9] G. Wang, "Determination of the expansion force of coarse steel slag aggregate," Construction and Building Materials, vol. 24, no. 10, pp. 1961-1966, 2010.

[10] American Society for Testing and Materials, "Standard test method for potential expansion of aggregate from hydration reactions," ASTM D4792-00p, 2006.

[11] M. S. Tang, M. Q. Yuan, and X. Shen, "The crystalline state of $\mathrm{MgO}, \mathrm{FeO}$ and $\mathrm{MnO}$ in steel slag and the soundness of steel slag cement," Journal of the Chinese Ceramic Society, vol. 7, pp. 3546, 1979 (Chinese).

[12] X.-K. Hou, D.-L. Xu, B. Xue, and H.-S. Li, "Study on volume stability problems of cement caused by steel slag," Journal of Building Materials, vol. 15, no. 5, pp. 588-595, 2012 (Chinese).

[13] H. S. Shi, "Microstructure and hydration activity of $\mathrm{CaO}$," Journal of the Chinese Ceramic Society, vol. 22, pp. 117-123, 1994 (Chinese).

[14] W.-T. Kuo, C.-Y. Shu, and Y.-W. Han, "Electric arc furnace oxidizing slag mortar with volume stability for rapid detection," Construction and Building Materials, vol. 53, pp. 635-641, 2014.

[15] W.-T. Kuo and C.-Y. Shu, "Application of high-temperature rapid catalytic technology to forecast the volumetric stability behavior of containing steel slag mixtures," Construction and Building Materials, vol. 50, pp. 463-470, 2014.

[16] E. Belhadj, C. Diliberto, and A. Lecomte, "Properties of hydraulic paste of basic oxygen furnace slag," Cement and Concrete Composites, vol. 45, pp. 15-21, 2014.

[17] L. B. Liao and G. Z. Xia, Crystal Chemistry and Crystal Physics, Science Press, Beijing, China, 2013 (Chinese).

[18] P. S. Liu, The Foundation of Crystal Point Defect, Science Press, Beijing, China, 2010 (Chinese).

[19] S. T. Li, X. L. Qiao, J. G. Chen, H. S. Wang, F. Jia, and X. L. Qiu, "Effects of temperature on indium tin oxide particles synthesized by co-precipitation," Journal of Crystal Growth, vol. 289, no. 1, pp. 151-156, 2006.

[20] A. Q. Ma, Y. Ren, and F. Duan, The Foundation of Inorganic Nonmetallic Material Science, Metallurgical Industry Press, Beijing, China, 2010, 2010 (Chinese). 
[21] T. Higuchi, M. Eguchi, M. Morioka, and E. Sakai, "Hydration and properties of expansive additive treated high temperature carbonation," Cement and Concrete Research, vol. 64, pp. 11-16, 2014.

[22] T. Sugiyama, Metal Oixide and Catalysis, Press of University of Science and Technology of China, Hefei, China, 1991 (Chinese). 

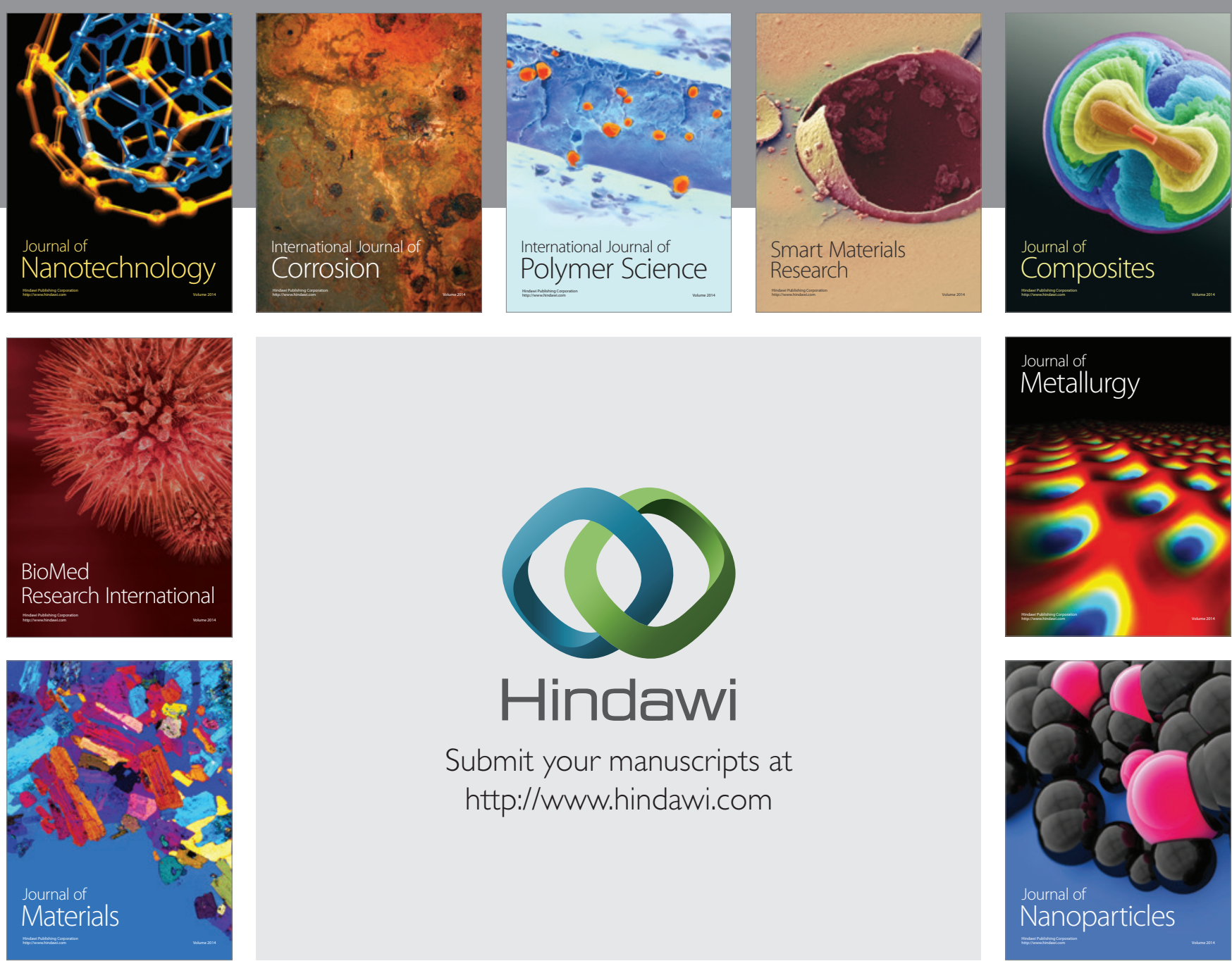

\section{Hindawi}

Submit your manuscripts at

http://www.hindawi.com

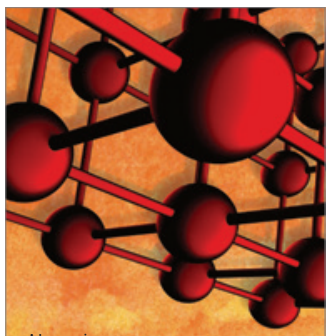

Materials Science and Engineering
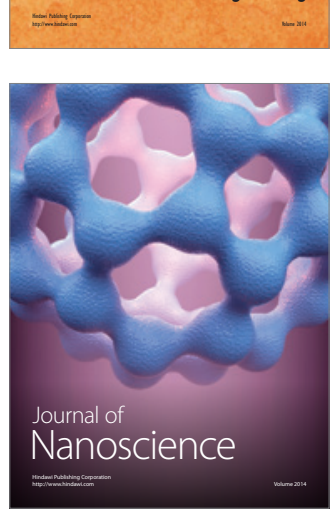
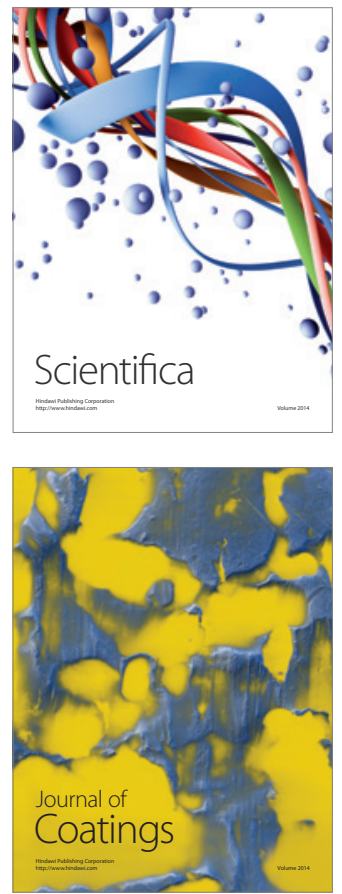
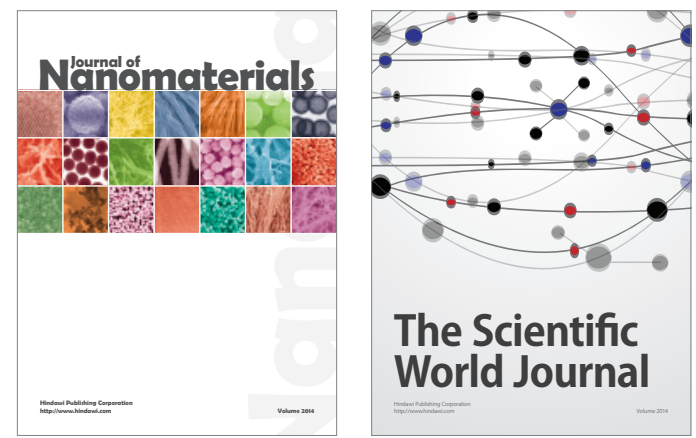

The Scientific World Journal
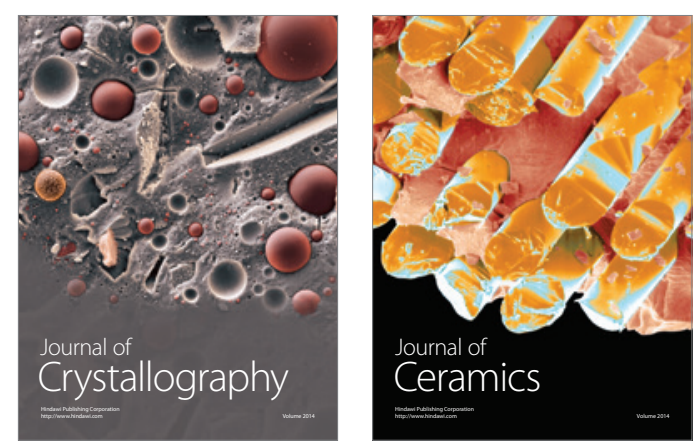
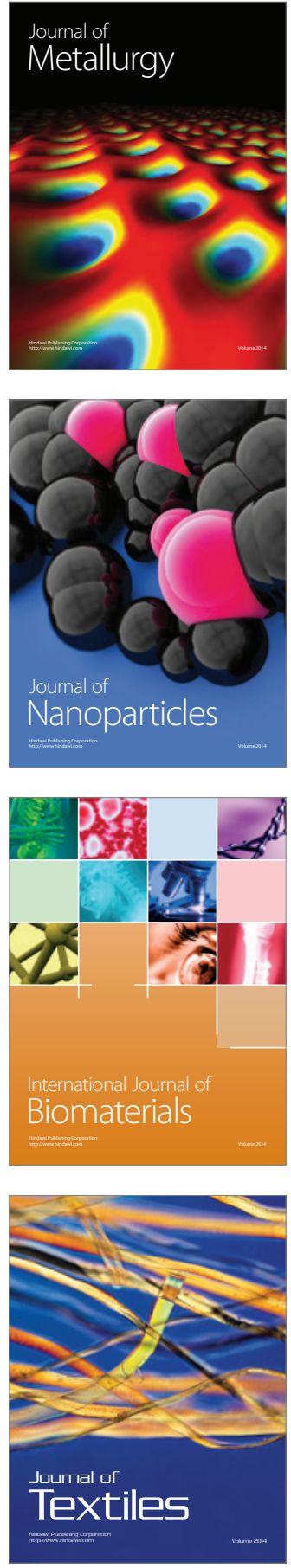